Portland State University

PDXScholar

$9-11-2020$

\title{
A Seasonal Study of Ecoroof Metal and Nutrient Dynamics and Associated Drivers in an Ecoroof on a Commercial Building in North Portland Oregon
}

Alex Vijay Bans

Portland State University

Follow this and additional works at: https://pdxscholar.library.pdx.edu/open_access_etds

Part of the Water Resource Management Commons

Let us know how access to this document benefits you.

\section{Recommended Citation}

Bans, Alex Vijay, "A Seasonal Study of Ecoroof Metal and Nutrient Dynamics and Associated Drivers in an Ecoroof on a Commercial Building in North Portland Oregon" (2020). Dissertations and Theses. Paper 5577.

https://doi.org/10.15760/etd.7449

This Thesis is brought to you for free and open access. It has been accepted for inclusion in Dissertations and Theses by an authorized administrator of PDXScholar. Please contact us if we can make this document more accessible: pdxscholar@pdx.edu. 
A Seasonal Study of Ecoroof Metal and Nutrient Dynamics and Associated Drivers in an Ecoroof on a Commercial Building in North Portland Oregon

\author{
by \\ Alex Vijay Bans \\ A thesis submitted in partial fulfillment of the \\ requirements for the degree of \\ Master of Science \\ in \\ Environmental Science and Management
}

Thesis Committee:

Jennifer Morse, Chair

Olyssa Starry

Eugene Foster

Portland State University

2020 


\section{Abstract:}

Green stormwater infrastructure (GSI), specifically ecoroofs, is increasingly seen as an effective stormwater management tool in urban planning strategies. However, the literature suggests that ecoroofs can be sources of certain metals and nutrients. The goal of our study was to address two research questions: 1) How does ecoroof runoff compare to conventional roof runoff chemically: do ecoroofs retain certain chemicals and leach others? and 2) what are the roof characteristics and environmental variables that affect runoff quality? For 10 months, runoff events from an ecoroof were compared to those of a conventional roof; water samples were collected with autosamplers, and flow was measured with a flow meter. Samples were analyzed for metals by mass spectrometry, and nutrients were analyzed by colorimetry. The ecoroof retained about $38 \%$ of the 577 $\mathrm{mm}$ of rainfall measured during the sampling period, and retention was closely associated with temperature and storm intensity. The ecoroof was a net source of $\mathrm{Al}, \mathrm{Fe}$, and $\mathrm{PO}_{4}{ }^{-3}$ while retaining chemicals that were a source from the conventional roof such as $\mathrm{Zn}$ and Cd. Ecoroof orthophosphate unit area loads were controlled by precipitation and temperature. More research needs to be done to improve ecoroof technologies including water treatment residuals, biochar, and mycorrhizae inoculation, which may help prevent the release of pollutants from ecoroof media. 


\section{Acknowledgements:}

Thank you, NSF grant, \# 1605843.

Time is the most precious commodity we have, so thank you to all of the people who invested it into this project, and more importantly, me.

I want to thank Dr. Olyssa Starry, Dr. Jennifer Morse, Dr. Gene Foster, Julia Bond, Tim Kurtz, Adrienne Aiona, Ivy Dunlap, Henry Stevens, Amy Simpson, and Alice Cooker for their knowledge and guidance. Thank you, Jason Law, Dr. Kelly Gleason and Dr. Pan, for programming, hydrology and statistics help. Thank you, Jordan LeaJames, Scott Kiel, Trevor Williams, Pradeep Ramasubramanian, and Dr. Hannah Prather, for the lab and field help. Thank you, members of the Morse Biogeochemistry lab and my cohorts of the ESM department, for inspiring me.

Lastly, thank you to my loved ones, my family, SGL, and everybody else I neglected to mention. 


\section{Table of Contents}

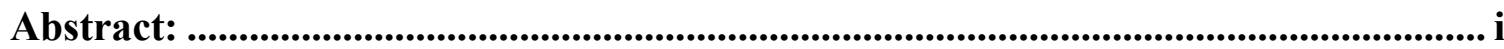

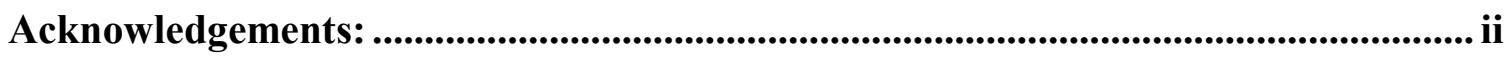

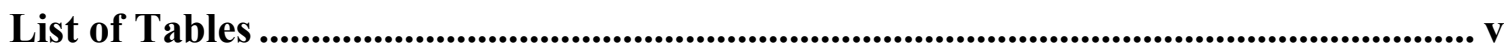

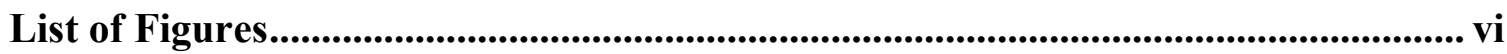

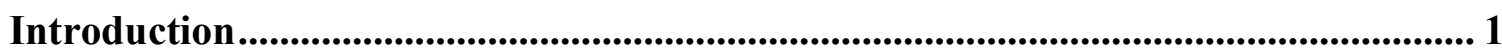

THE URBAN ENVIRONMENT AND ITS CONCERNS …………….................................................................... 1

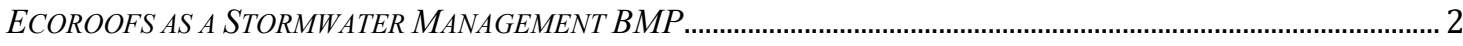

STUDY OBJECTIVES

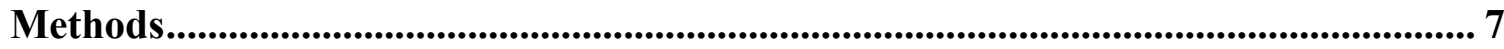

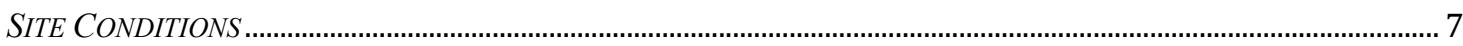

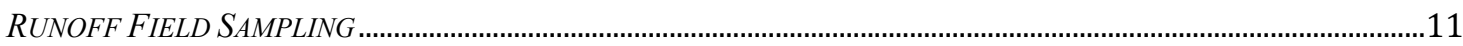

ENVIRONMENTAL AND ROOF CONDITION FIELD SAMPLING …….................................................................13

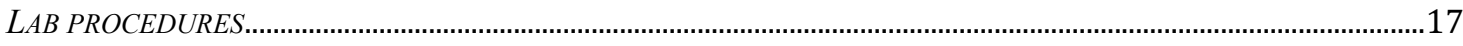

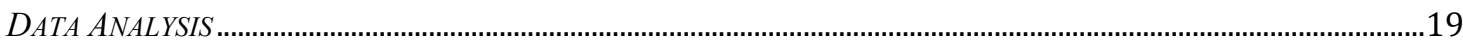

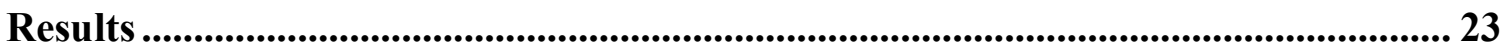

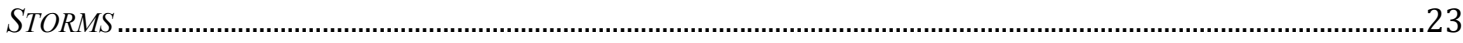

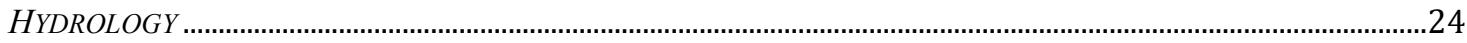

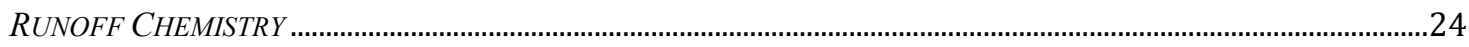

ANALYSIS OF ENVIRONMENTAL AND ROOF VARIABLES

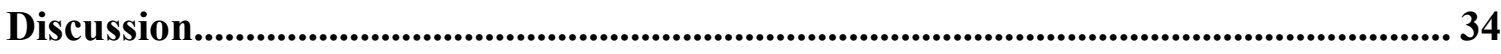

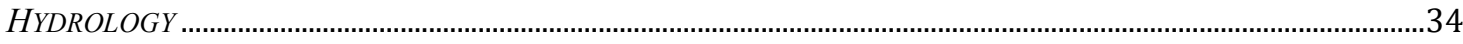

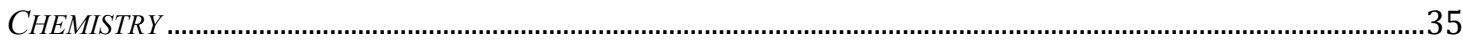

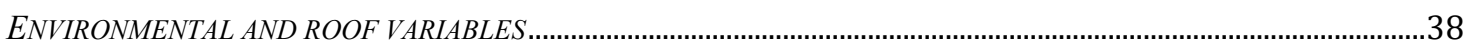

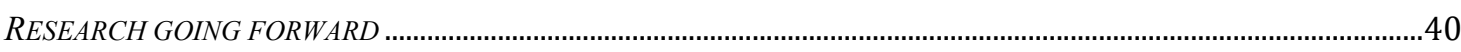

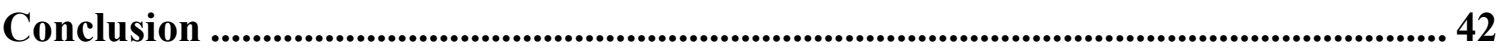

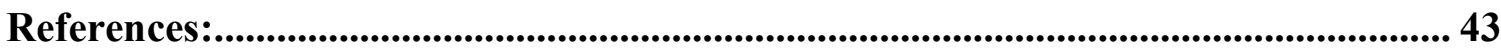

Appendix A: Storm summaries .................................................................................. 46

Appendix B: Sample collection ..................................................................................... 47

Appendix C: Runoff Concentration Summaries.............................................................. 48

Appendix D: Broken Stick Model ................................................................................... 49

Appendix E: PCA Eigenvectors................................................................................ 50

Appendix F: Runoff Chemical Unit Area Loading Summary .................................. 51 
Appendix G: Roof Bulk Deposition Input Concentrations ...................................... 52

Appendix H: The Flow Chart of the Experiment Design ....................................... 53 


\section{List of Tables}

Table 1. A summary of ecoroof literature comparing instances when ecoroof runoff concentrations are higher than conventional roof runoff. Grey denotes that ecoroof runoff was not higher than the conventional roof, black denotes ecoroof runoff was higher than conventional roof, white denotes no data.

Table 2. The total bulk deposition unit area load of metals entering the ecoroof research

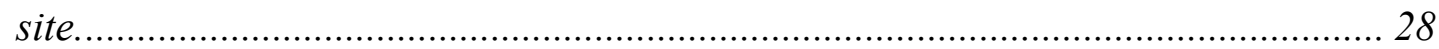

Table 3. The ecoroof media analysis over 4 years....................................................... 30

Table 4. The percent of samples collected from the conventional roof and ecoroof that exceed the DEQ 1200-z permit. Permit values were total concentrations while runoff samples were dissolved concentrations................................................................... 36

Table 5. The percent of samples collected from the conventional roof and ecoroof that exceed DEQ in-stream aquatic chronic water quality standards. Water quality standard values were dissolved concentrations, excluding $F e$, while runoff samples were dissolved concentrations. 37 


\section{List of Figures}

Figure 1. Birds eye view of the ecoroof research site. 7

Figure 2. Rooftop view of ecoroof and conventional roof project site. .............................. 8

Figure 3. Schematics of the ecoroof layers (Miller, Personal communication, August $2^{\text {nd }}$, 2019)

Figure 4. Examples of plants located on the ecoroof site. Top row left to right: Sedum takesimense with Dianthus deltoides; Erodium cicutarium with Plectritis congesta, Sedum divergens, and Sedum rupestre; Sedum floriferum. Bottom row: Dianthus deltoides; Coreopsis, lanceolata; Plectritis congesta....................................... 10

Figure 5. The conventional roof flume, flow meter, and autosampler set up ................. 12

Figure 6. HYDRA tipping rain gauge. ............................................................................ 14

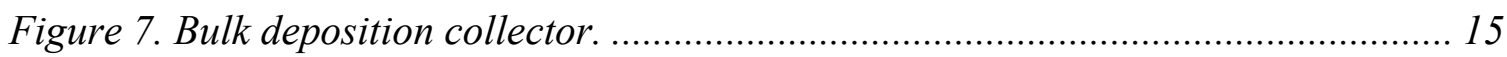

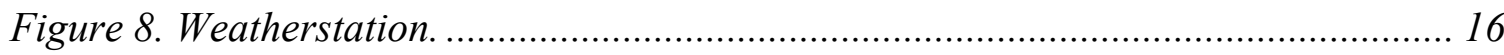

Figure 9. The ICP-MS used for analyzing trace metal concentrations. .......................... 18

Figure 10. SmartChem used for analyzing nutrients............................................. 18

Figure 11. The histogram of the precipitation events over the sampling period over both roofs organized in $10 \mathrm{~mm}$ bins. .............................................................................. 23

Figure 12. The hyetograph and hydrograph of the conventional roof and ecoroof over the

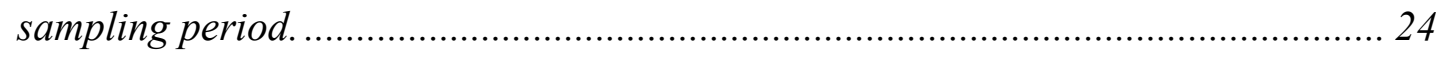

Figure 13. The roof stormwater runoff concentrations of select metals and nutrients of ecological importance, or with an established in-stream water quality standard, criteria, or benchmark, from the conventional roof (red), and ecoroof (blue), over the entire sampling period...................................................................................... 26

Figure 14. The Principal Component Analysis of ecoroof hydrology and unit area loads over the 27 storm events.

Figure 15. The metal runoff concentrations from the gutter testing from the ecoroof and conventional roof...... 31

Figure 16. The difference between the unit area loads of metals and nutrients of the conventional roof over the sampling period. Above 0 shows when the conventional roof has higher unit area loads compared to the ecoroof and below 0 shows when the ecoroof has higher unit area loads compared to the conventional roof...... 


\section{Introduction}

The Urban Environment and its Concerns

The growth of urban environments will increase the ecological impact of cities (Grimm et al., 2008). Increasing impervious surfaces, like roads, sidewalks, driveways, roofs and building footprints, lessens precipitation infiltration into the ground, increasing the velocity and intensity of water runoff into urban streams (Arnold, and Gibbons, 1996; Paul, and Meyer, 2001). Urban runoff can increase the runoff intensity and peak flows of rivers, changing physical morphology, increasing depth, erosion, and scouring (Anim et al; 2017, Walsh et al; 2005).

Dry and wet deposition of atmospheric metals, from sources such as the burning of fossil fuels, can contribute to at least half of the pollutants in stormwater (Sabin et al. 2005). The runoff from urban environments is often too warm and, in addition to metals, can be contaminated with harmful chemicals and excessive nutrients, leading toxicity and eutrophication of natural waterbodies (Carpenter et al., 1998; Paul, and Meyer, 2001), interference with essential vertebrate biological functions (Wang et al. 2013, McIntyre et al. 2014), and vertebrate die offs (Scholz et al. 2011, Wu et al. 2014, McIntyre et al. 2015). 
Ecoroofs as a Stormwater Management BMP

A strategy for mitigating the environmental impact of urbanization is to decrease the extent of impervious surfaces by increasing the amount of natural vegetation in cities, allowing for reduction in runoff quantity and velocity. Best management practices (BMPs) include bioretention facilities (i.e., planters and rain gardens), pervious asphalt and concrete, and ecoroofs, also known as green roofs (Dietz, 2007). Ecoroofs are increasingly becoming important tools in vegetation-based stormwater management of cities for reducing urban runoff and increasing its quality. For instance, the City of Portland promotes ecoroofs for both onsite stormwater management and city zoning code (City of Portland, N.D).

Ecoroofs offer important hydrological ecosystem services to the urban environment along with reducing impervious surface area. All over the world, in cities such as Toronto, Canada (Van Seters et al. 2009), Chongqing, China (Zhang et al. 2015), and Portland, Oregon (Schroll et al. 2011; BES 2013), much research has gone into measuring the precipitation retention of these systems. Studies suggest the typical precipitation retention of ecoroofs range from about $35.5 \%$ to $70 \%$ depending on roof size, configuration, and climate (Van Seters et al. 2009; Zhang et al. 2015). The precipitation retention of ecoroofs in the climate of Portland, Oregon, ranges from $12 \%$ to 70\% depending on substrate depth (Spolek 2008; BES 2013).

On the other hand, stormwater runoff quality from ecoroofs has been difficult to measure and has produced mixed results in past studies. Table 1 is a summary of various 
ecoroof water quality studies which highlights the instances of when select concentrations of chemicals of ecological concern from ecoroof runoff exceed conventional roof runoff. Ecoroof runoff concentration data tends to have variable results. Due to this variability, it is important to further examine these chemicals and what factors affect them, to better predict ecoroof behavior in order to prevent unintentional ecosystem disservices.

In terms of ecoroof test trays, concentrations of $\mathrm{Na}, \mathrm{Mg}, \mathrm{Fe}$, and $\mathrm{NO}_{3}^{-}$, and $\mathrm{Pb}$ tend to be higher in some media and plant combinations and test plots, but ecoroofs have been shown to sometimes retain dissolved $\mathrm{Cu}$ and $\mathrm{Zn}$ concentrations in the runoff (Van Seters. 2009; Vijayaraghavan et al. 2012; Zhang et al. 2015). On roof-scale ecoroofs there have been inconsistent findings with how $\mathrm{NO}_{3}{ }^{-}$concentrations compare between the runoff of precipitation, conventional roofs, and ecoroofs (BES 2013; Speak et al. 2014; Buffam et al. 2016). However, $\mathrm{Fe}, \mathrm{Pb}$, and $\mathrm{PO}_{4}^{-3}$ are often of concern in ecoroof runoff. 
Table 1. A summary of ecoroof literature comparing instances when ecoroof runoff concentrations are higher than conventional roof runoff. Grey denotes that ecoroof runoff was not higher than the conventional roof, black denotes ecoroof runoff was higher than conventional roof, white denotes no data.

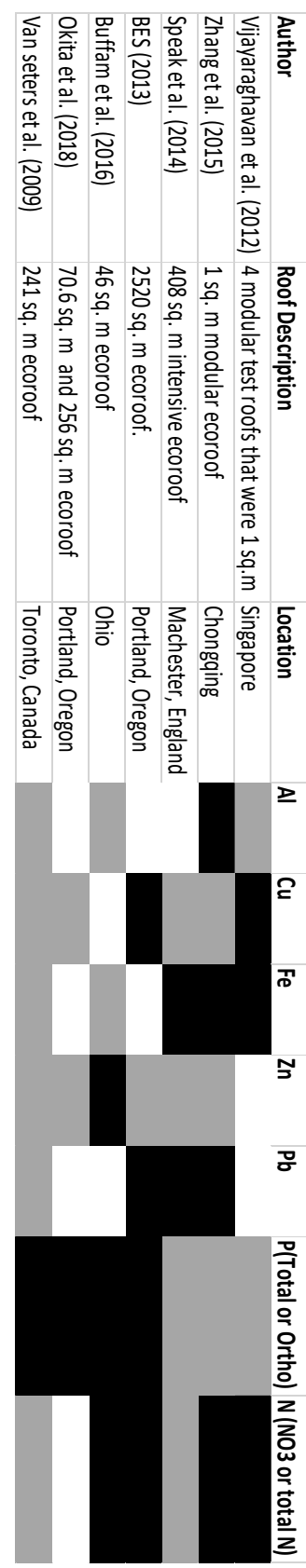


There are a few potential reasons why the results of these studies vary so much. One potential explanation of the variance of results between the studies is seasonality. There is evidence that temperature, a proxy for seasonality was correlated with the variation in runoff chemistry (Buffam et al. 2016). Additionally, there were higher levels of $\mathrm{Mg}, \mathrm{Na}, \mathrm{N}$, and $\mathrm{P}$ in summer compared to winter. Concentrations of $\mathrm{Al}, \mathrm{Fe}$, and $\mathrm{Zn}$ did not appear to have much seasonality.

Another potential source of variability is the age of the facility. In Portland, Okita et al. (2018), studied two ecoroofs that were 6-months old and 6 years old and found that during the course of the study that total $\mathrm{P}$ and $\mathrm{PO}_{4}{ }^{-3}$ were higher in runoff from both ecoroofs compared to a conventional roof and that the newer roof had higher levels. Long term analysis of multiple ecoroofs in Portland shows that ecoroofs tend to be higher in $\mathrm{Pb}$ and $\mathrm{PO}_{4}^{-3}$, and that conventional roofs tend to have higher concentrations of $\mathrm{Cu}$, likely due to roof material (Deshmukh, 2019). Additionally, it was found that total $\mathrm{P}$ and $\mathrm{PO}_{4}{ }^{-3}$ levels were decreasing over time in multiple ecoroofs as well.

Finally, there is a difficulty in accounting for both runoff chemical concentrations and discharge of the ecoroof. Looking at unit area load of metals and nutrients is important as it is the value incorporates both of those variables. It is important to note that if only concentrations are examined instead of also unit area loading, different conclusions may be drawn. A study in Toronto found that a $241 \mathrm{~m}^{2}$ ecoroof had higher unit area loads of total $\mathrm{P}, \mathrm{PO}_{4}^{-3}$, and $\mathrm{Pb}$ compared to a $131 \mathrm{~m}^{2}$ conventional roof, while the conventional roof had higher unit area loads of $\mathrm{Al}, \mathrm{Cd}, \mathrm{Cr}, \mathrm{Cu}, \mathrm{Fe}$, and $\mathrm{Zn}$ (Van Seters et al. 2009). Zhang et al. found higher unit area loads of $\mathrm{NO}_{3}{ }^{-}$, but found that 
ecoroofs had lower unit area loads of dissolved $\mathrm{Cu}, \mathrm{Fe}, \mathrm{Zn}$, and $\mathrm{Pb}$. Findings from these two studies are mostly consistent in terms of metals but not with respect to nutrients. More work is needed to clarify these discrepancies and build a growing body of research on this subject that can help elucidate the mechanisms explaining variation in the quality of ecoroof runoff.

\section{Study Objectives}

By analyzing, the stormwater hydrology and chemistry of a seven-year-old ecoroof on top of a commercial building we hoped to answer two major questions:1) How does ecoroof runoff compare to the conventional roof runoff chemically and 2) what are the roof characteristics and environmental variables that affect runoff quality? The roof factors investigated were soil media and the contribution of metals from the roof gutters. The environmental factors investigated include temperature, humidity, wind speed, metal bulk deposition, antecedent dry period, precipitation, storm intensity, and storm length. This research is important to further capture the variation in ecoroof chemistry and attempt to understand the drivers of these variations with a high sample collection frequency.

As stormwater management practices are expanding to utilize green

infrastructure, it is important that we understand these processes to both avoid unintended consequences as well as to maximize potential benefits. This information can also be used to inform future design decisions. 


\section{Methods}

A flow chart summary of the method design is provided in Appendix $H$.

\section{Site Conditions}

The study took place at a commercial building located in North Portland, Oregon (longitude $=-122.59611111$, latitude $=45.59555556$ ), from August 2018 to the beginning of June 2019 (Figure 1). Portland has a temperate climate, in which temperatures range from about $6 \mathrm{C}$ to $11 \mathrm{C}$ annually with an average precipitation of about $940 \mathrm{~mm}$, with about 95\% of the city's precipitation occurring between August and May (NOAA, 2020).

The roof was completed in 2013 and covers approximately $6,700 \mathrm{~m}^{2}$. The building roof has two portions, an ecoroof on the west half, and a conventional roof on the east half

\section{(Figure 2).}

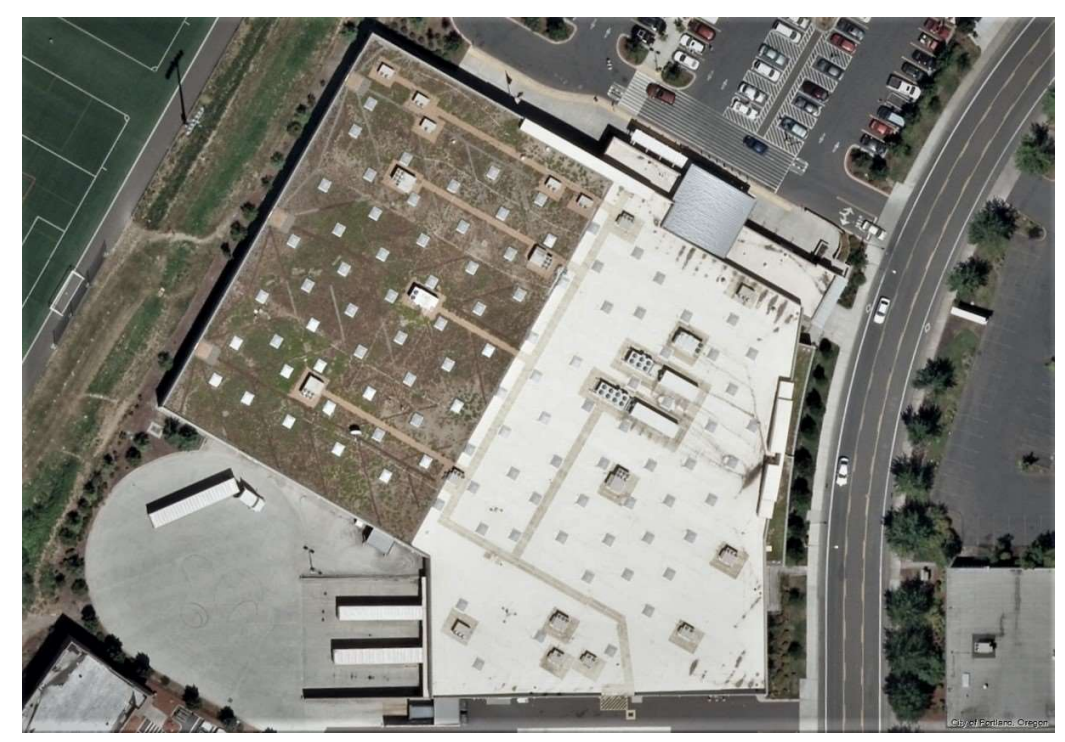

Figure 1. Birds eye view of the ecoroof research site. 


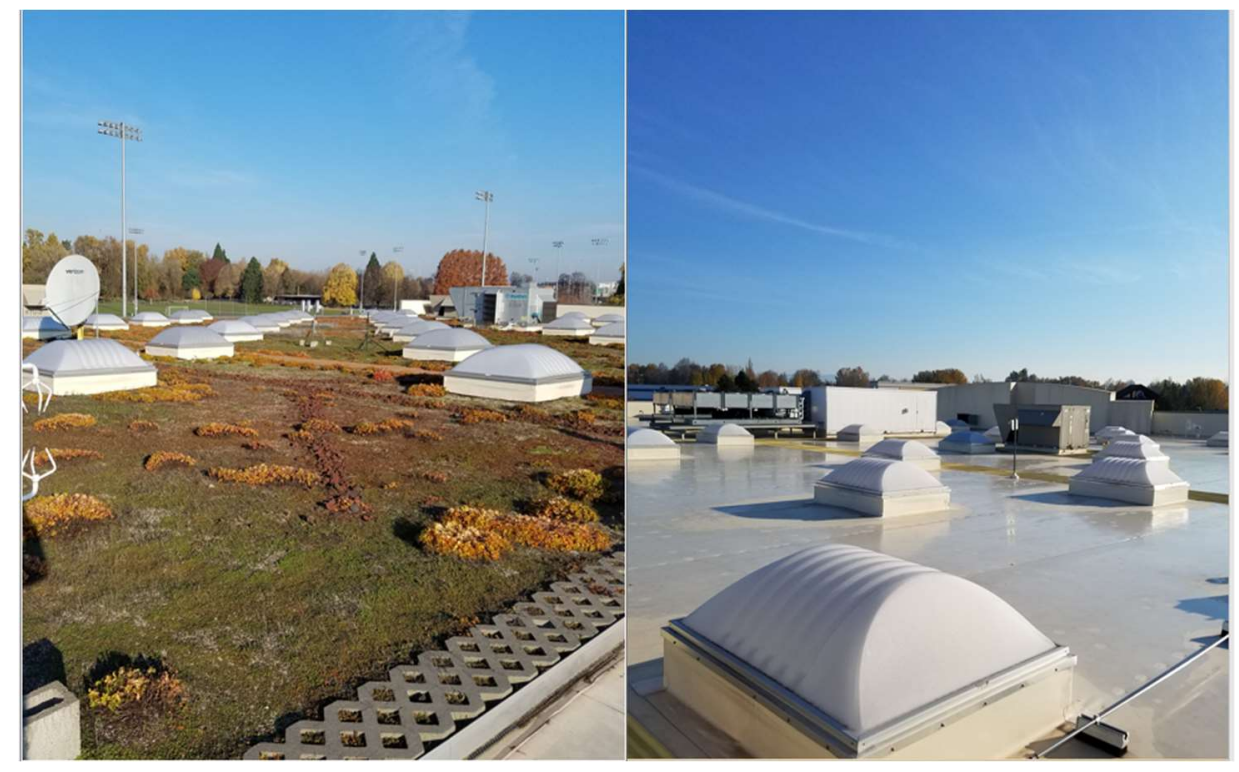

Figure 2. Rooftop view of ecoroof and conventional roof project site.

The ecoroof itself is divided into 3 sections that are about $1,200 \mathrm{~m}^{2}$ each, that differ in growing media depth: the southernmost section is $127 \mathrm{~mm}$ in depth, the middle section ranges from $76 \mathrm{~mm}$ to $127 \mathrm{~mm}$, and the northernmost section is about $76 \mathrm{~mm}$ depth. The growing media is a blend of pumice, and compost (Figure 3). There is a capillary fabric underneath two layers of growth media and then a layer of scoria rock on top. The purpose of the filter is to distribute the moisture evenly in the media and allow water to flow through easily. 


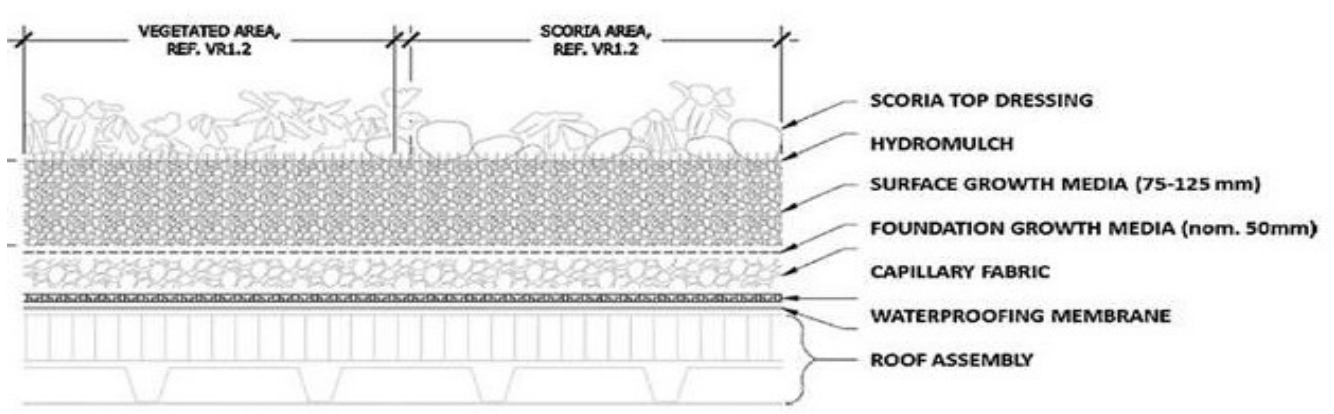

Figure 3. Schematics of the ecoroof layers (Miller, Personal communication, August $2^{\text {nd }}$, 2019).

The southernmost drainage section of the conventional roof, which catchment area totaled about $1,468 \mathrm{~m}^{2}$, and the ecoroof runoff, accelerated by siphonic drains, are routed separately through to the southern part of the building and into Contech filters and vegetated facilities respectively.

The ecoroof has many types of plants: Sedum takesimense, Dianthus deltoides, Erodium cicutarium, Plectritis congesta, Sedum divergens, and Sedum kamtshaticum (Figure 4). While many of these plants are evergreen, they flower from May to July. The roofs were maintained regularly by the building owner through activities such as removal of non-desirable vegetation and seeding additional plants. The roof was not fertilized during the study. 


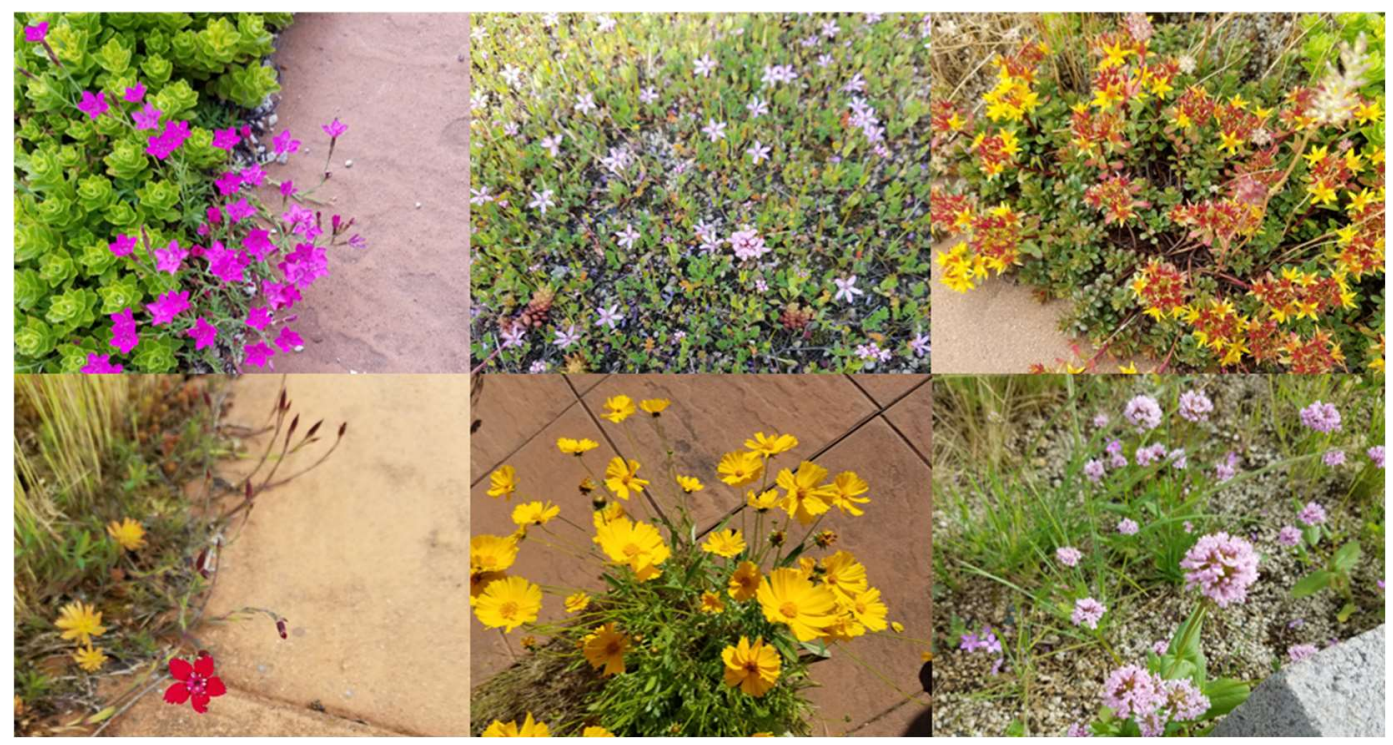

Figure 4. Examples of plants located on the ecoroof site. Top row left to right: Sedum takesimense with Dianthus deltoides; Erodium cicutarium with Plectritis congesta, Sedum divergens, and Sedum rupestre; Sedum floriferum. Bottom row: Dianthus deltoides; Coreopsis, lanceolata; Plectritis congesta.

From February 9th, 2019 to February 11th, 2019 both the conventional roof and ecoroof were covered in snow. In the months of November 2018 and December 2018, there was minor leakage of water into the skylights of the building and the roof needed repairs. As repairs were minor, samples from that period were still used.

While regular irrigation was not done during the duration of the study, there was minor watering done during 3 storm events to test for leaks, and replanting during the roof repairs. Watering occurred on September $7^{\text {th }}, 25^{\text {th }}$, and $27^{\text {th }} 2018$; February $15^{\text {th }}$ through $28^{\text {th }} 2019$; April $4^{\text {th }}$ through $6^{\text {th }} 2019$; and finally, May $8^{\text {th }}$ through $11^{\text {th }} 2019$. 
Runoff Field Sampling

Runoff flow from the southernmost drainage section of the conventional roof and $76 \mathrm{~mm}$ deep portion of the ecoroof was monitored with XL trapezoidal Plasti-Fab flumes outfitted with Hach US9001 down-looking ultrasonic depth sensors set to average flow measurements every 5 minutes (Figure 5). The meters and flume were maintained by the Portland Bureau of Environmental Services (BES) personnel who also conducted QA/QC once a month by testing the accuracy of the flow meters and flume by manually measuring depth. The flow meter for the conventional roof was not registering flow at the end of October 2018 but was replaced; as a result, the flow data for the month of October was not included in our study for both roofs. 


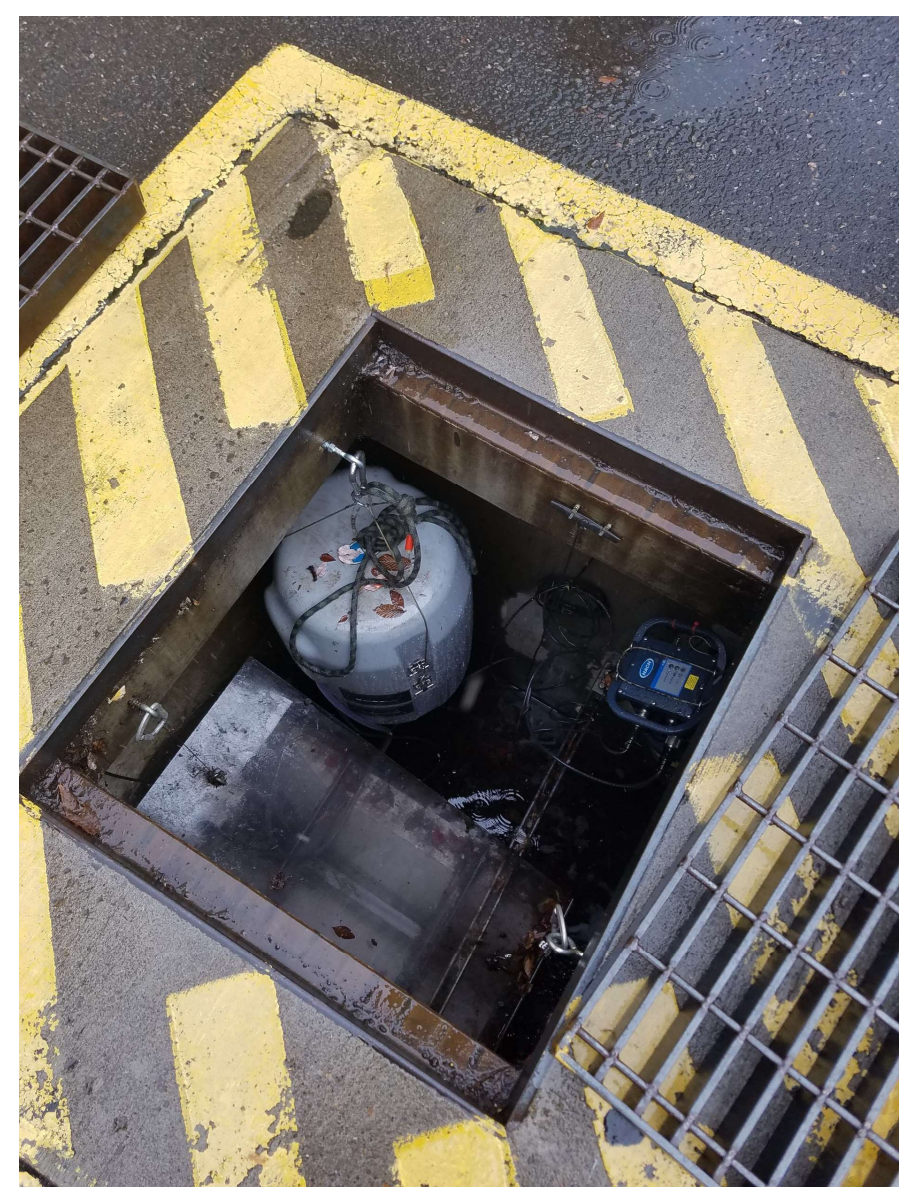

Figure 5. The conventional roof flume, flow meter, and autosampler set up.

Ruoff samples were collected from the conventional roof and the $76 \mathrm{~mm}$ ecoroof by 2 portable samplers (HACH AS950). The samplers connected to the flow meter were programmed remotely using an online interface (FSDATA). The autosamplers triggered when the runoff flow from the roof reached about $0.09 \mathrm{~L} / \mathrm{s}$. After the initial sampler trigger, continued sampling was dictated by a pacing interval volume. The initial pacing interval volume in summer was found by taking a typical estimated summer precipitation depth and duration and calculating what the volume coming off the roof would be, 
resulting in approximately $1,869 \mathrm{~L}$ for the conventional roof and $1,303 \mathrm{~L}$ for the ecoroof. As winter approached, the pacing interval volume was increased to about 2,800 L for the conventional roof and $1,954 \mathrm{~L}$ for the ecoroof to account for increased flow and allow for a similar number of samples during extended storms. For the month of April, it was decided to increase the sampling frequency to characterize, in high resolution, how metal and nutrient concentrations change during a storm event. This was achieved by reducing the pacing interval volume, so that the conventional roof pacing interval volume was set for about $1,331 \mathrm{~L}$ and the ecoroof pacing interval volume was set for about $935 \mathrm{~L}$. From the months of September through December, the autosampler for the ecoroof was not completely collecting the samples to the bottle and in some circumstances, samples needed to be combined until the arm was properly aligned.

\section{Environmental and Roof Condition Field Sampling}

Precipitation was measured using a tipping gauge on the roof which was part of the City of Portland HYDRA Rainfall Network maintained by BES (igure 6). The precipitation values were aggregated into 5-minute intervals. 


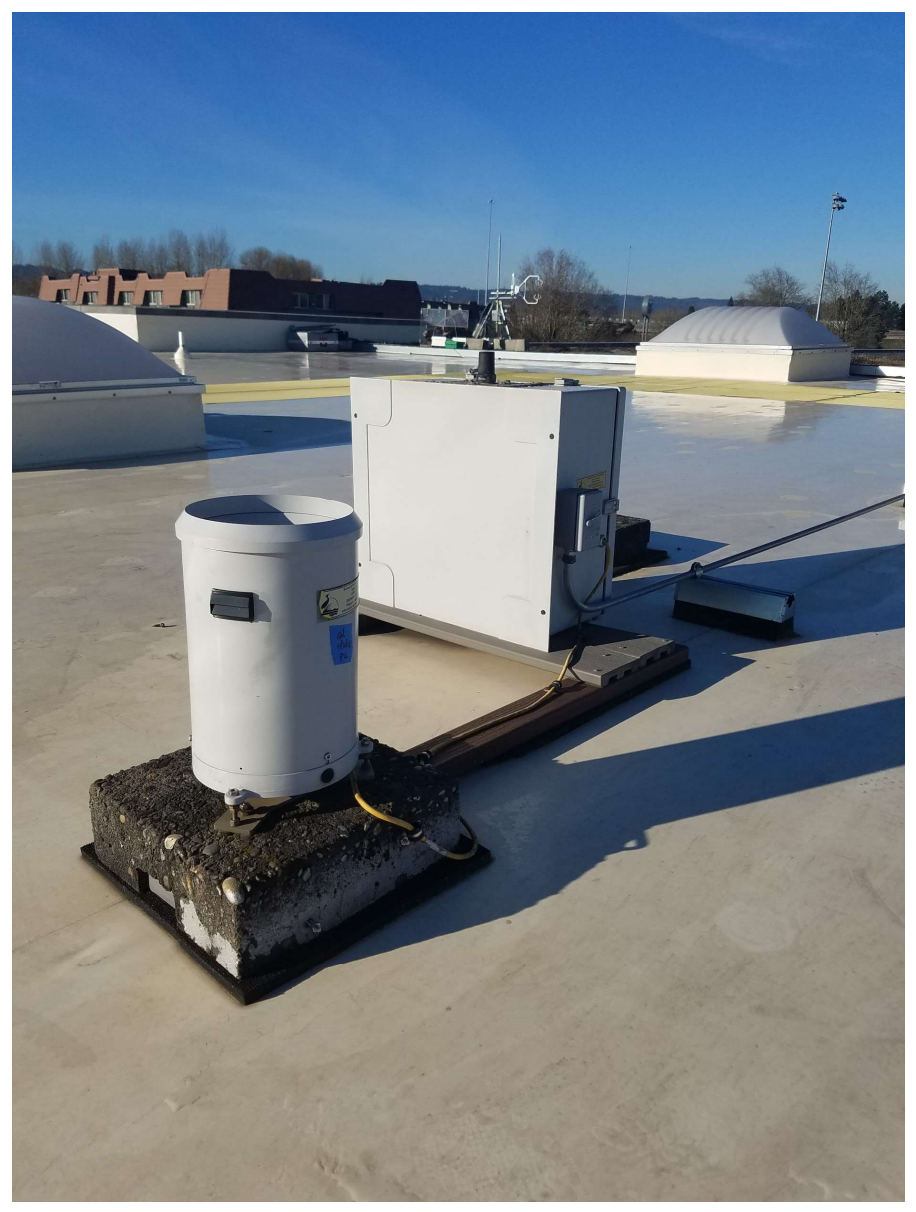

Figure 6. HYDRA tipping rain gauge.

Atmospheric bulk deposition input was sampled by 3 collectors and gathered around every 2 weeks (Figure 7). If no wet deposition had occurred, then $25 \mathrm{~mL}$ of $10 \%$ $\mathrm{HNO}_{3}$ was added before collection. Samples were preserved with $10 \% \mathrm{HNO}_{3}$ for 24 hours before filtration $0.45-\mu \mathrm{m}$ cellulose acetate or nylon filter. It is important to note that this method determines the total bulk deposition of metals, while our runoff sampling only determined the dissolved metal content. 


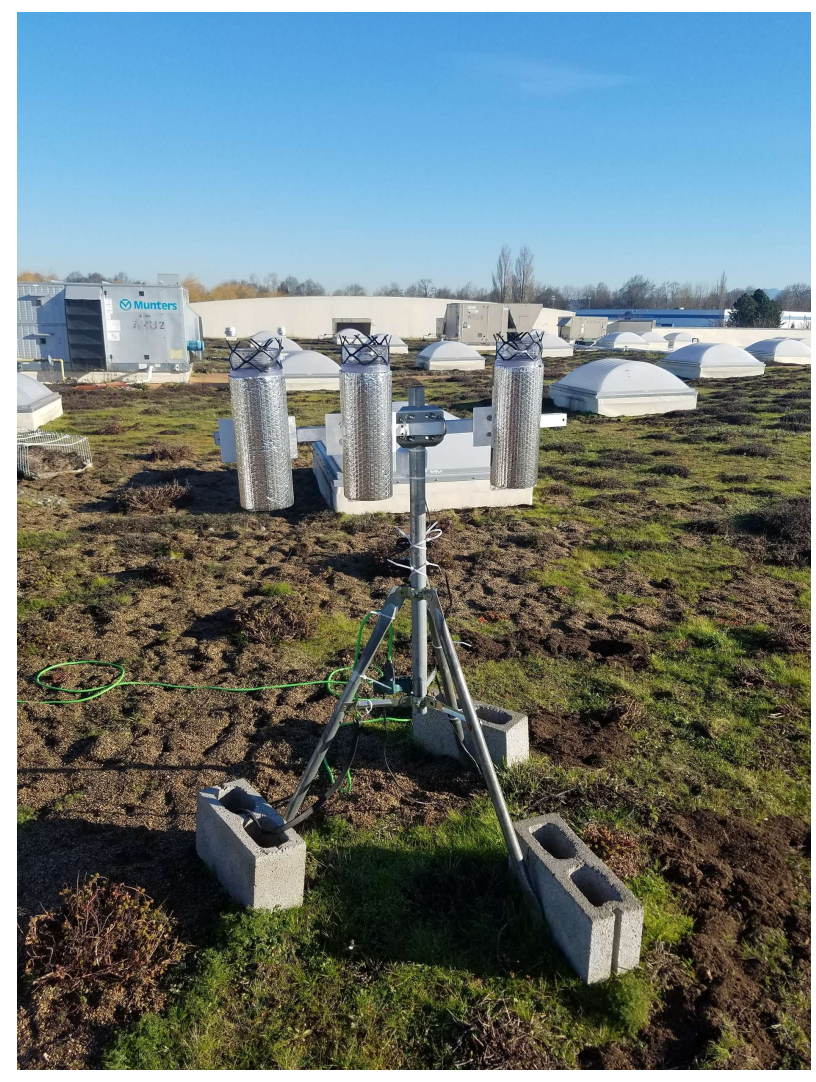

Figure 7. Bulk deposition collector.

Other environmental site conditions were recorded on site by a Campbell CR3000 Weatherstation with a Vaisala temperature/RH Probe and 03002-L Wind Sentry Set which recorded 15 min averaged measurements of air temperature, wind speed direction, albedo, solar radiation, and incoming and outgoing shortwave and longwave radiation (Figure 8). Weather station data was downloaded once a month. 


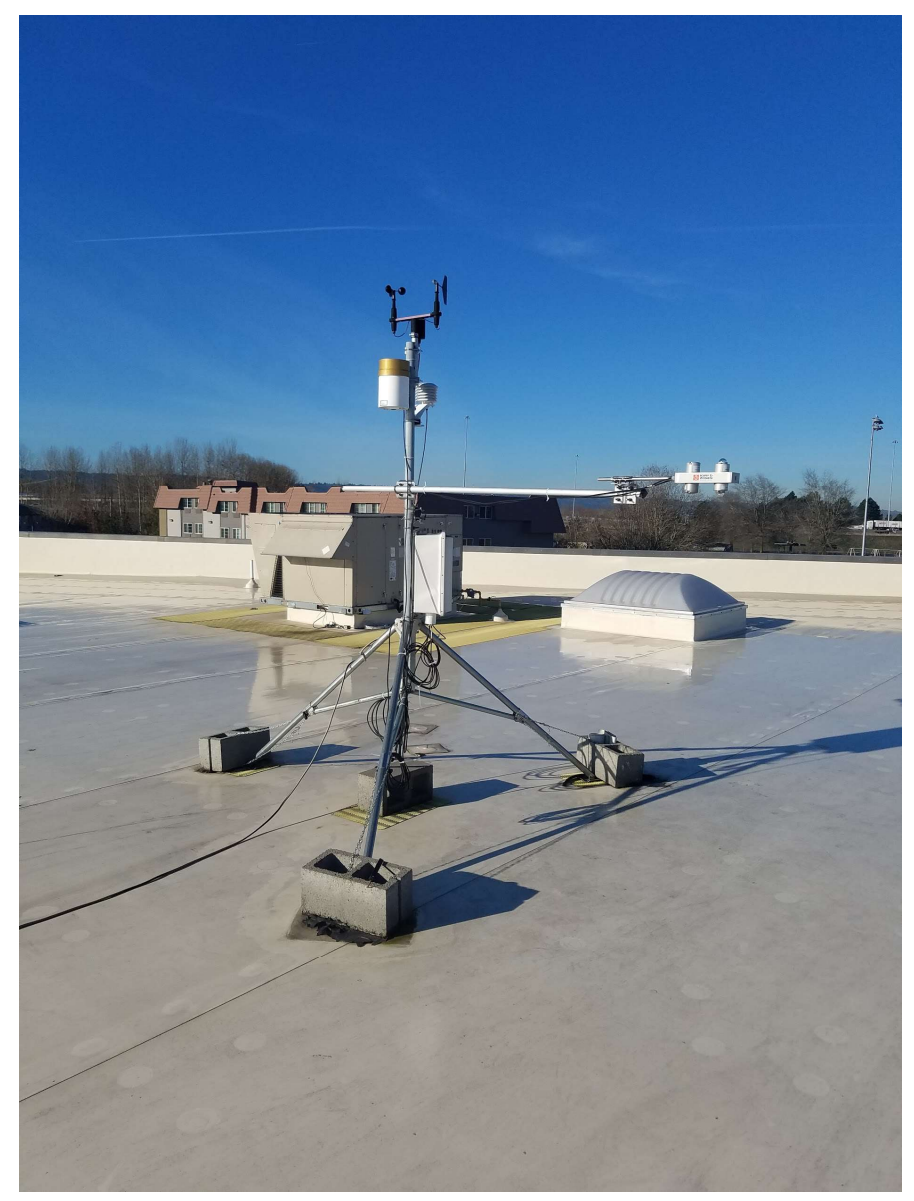

Figure 8. Weatherstation.

From 2014 to 2018, 5 gallons of randomly sampled ecoroof substrate from the ecoroof was collected annually and sent out each time to Penn State for analysis. The parameters being analyzed were $\mathrm{NO}_{3}-\mathrm{N}, \mathrm{NH}_{3}-\mathrm{N}, \mathrm{NH}_{4}, \mathrm{P}, \mathrm{Ca}, \mathrm{Na}, \mathrm{B}, \mathrm{Cu}, \mathrm{Fe}, \mathrm{Mg}, \mathrm{Zn}, \mathrm{Ca}$, $\mathrm{K}, \mathrm{Mg}$, soluble salts, and $\mathrm{pH}$. The results were used as a helpful guide to look at historical roof trends. 
Lab procedures

Runoff samples collected by the autosampler were usually retrieved within 48 hours and filtered with $0.45-\mu \mathrm{m}$ cellulose acetate or nylon filters. Beginning in October 2018, runoff samples for nutrient analysis were also collected, frozen and thawed the night before analysis. If samples were collected more than 48-hours before we could retrieve them, they were not selected for nutrient analysis, as there is a risk of microbial interactions changing the concentrations in the sample. DI water blanks were also collected in the field. Bulk deposition samples were preserved in $10 \% \mathrm{HNO}_{3}$ for 24 hours before being filtered by a $0.45-\mu \mathrm{m}$ cellulose acetate or nylon filter.

Runoff and bulk deposition samples were analyzed for metal concentrations using an Agilent ICP-MS 7900 located in the Geology Department of Portland State University for B, Na, Mg, Al, Ti, V, Cr, Mn, Fe, Co, Ni, Cu, Zn, As, Sr, Mo, Cd, Ba, and $\mathrm{Pb}(\underline{\text { Figure 9 }})$. Nutrient samples were analyzed with a SmartChem 170 discrete nutrient analyzer (Unity Scientific, CT) located in the Environmental Science and Management Department of Portland State University. $\mathrm{N}$ as $\mathrm{NO}_{3}-\mathrm{NO}_{2}$ (Method NO3-001-B) and orthophosphate (Method PHO-004-A) were analyzed (Figure 10). For the runoff samples, the lab blanks were subtracted to correct for reagent variability. 


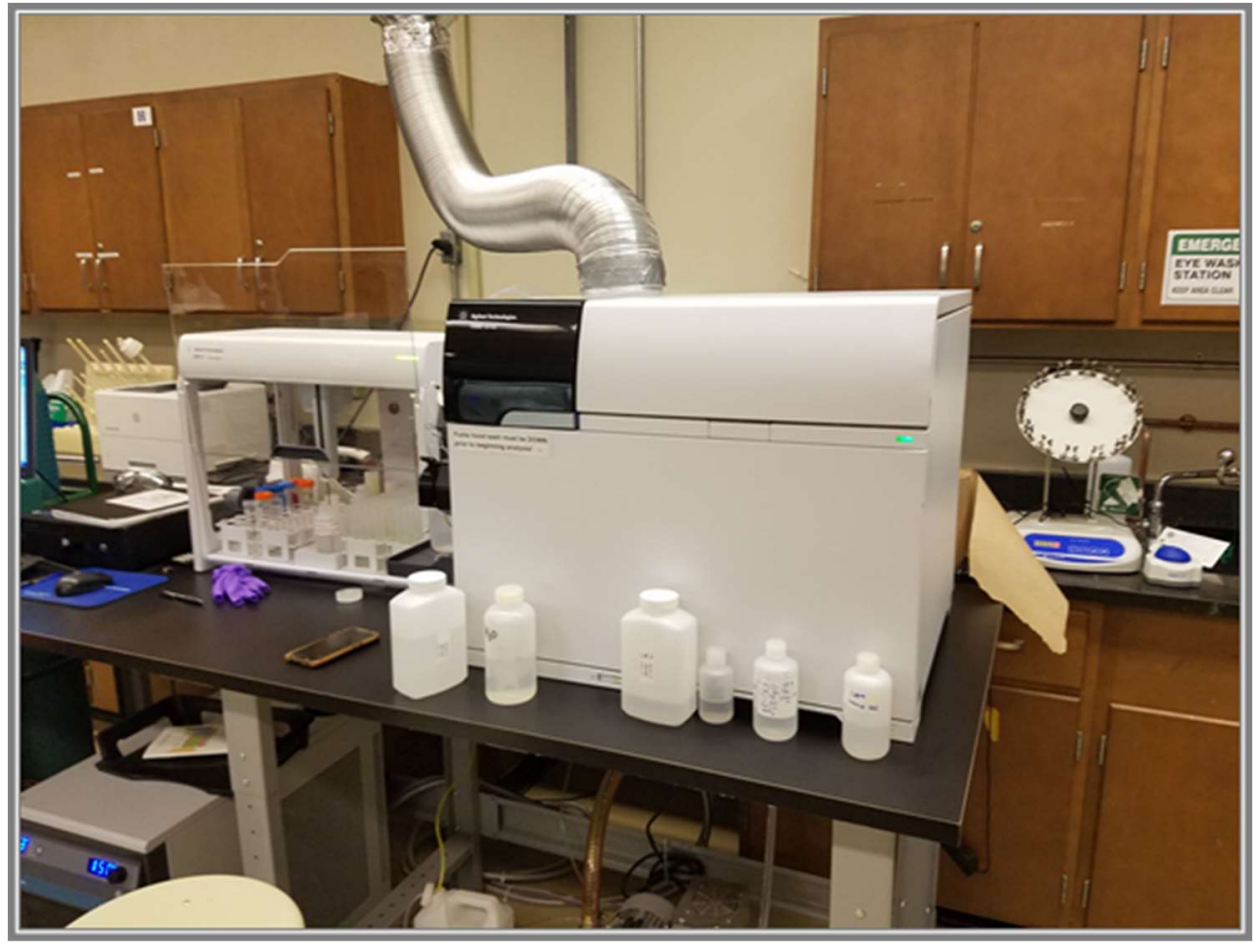

Figure 9. The ICP-MS used for analyzing trace metal concentrations.

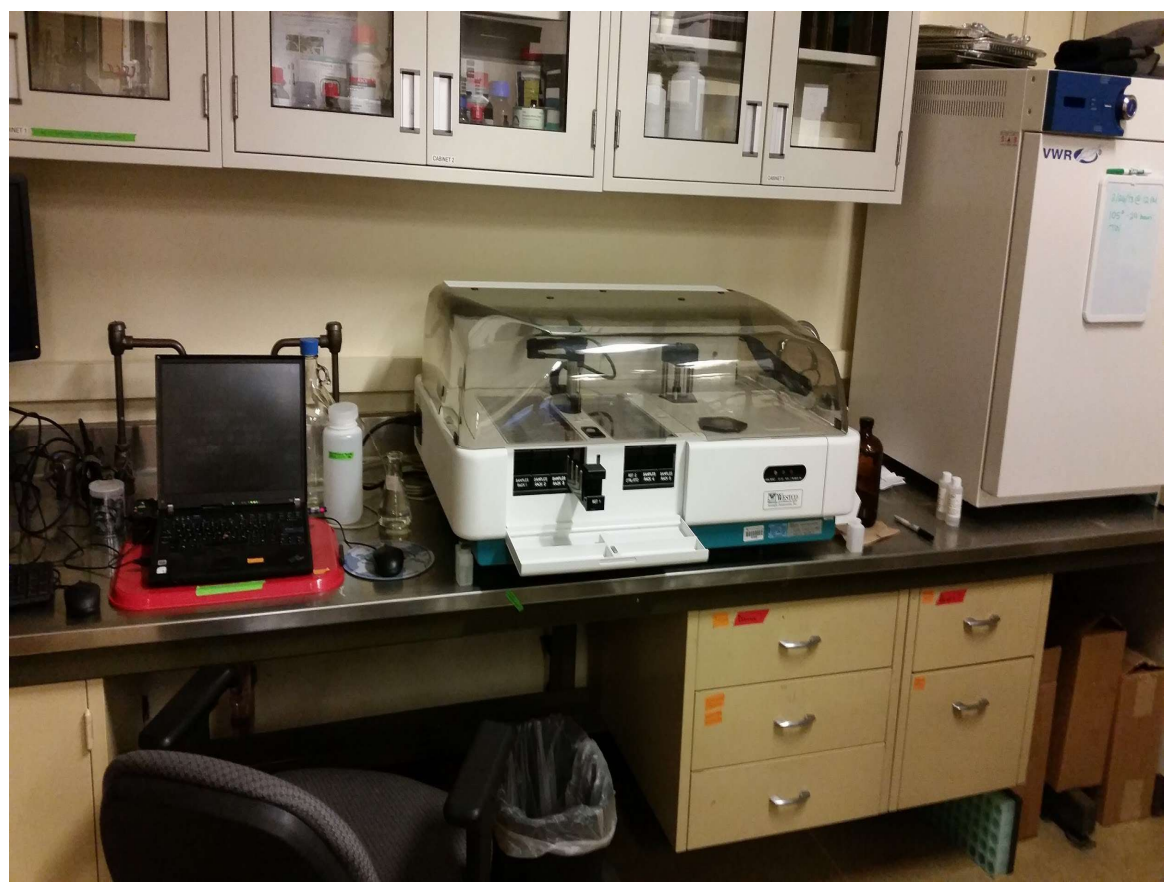

Figure 10. SmartChem used for analyzing nutrients. 


\section{Data Analysis}

All data was organized, manipulated, transformed, and analyzed with Rstudio (RStudio team 2016). The packages used for data manipulation and visualization were Tidyverse (Wickham et al.,2019), Lubridate (Grolemund and Wickham, 2011), and gridExtra (Auguie 2015). The packages used for statistical testing were Vegan (Oksanen et al., 2019), Factoextra (Kassambara and Mundt 2019), Farver (Lin et al., 2020), and Lmtest (Zeileis and Hothorn, 2002).

Precipitation, conventional roof runoff, and ecoroof runoff were separated into storm events, according to protocols established by BES, defined as having at least 0.254 $\mathrm{mm}$ of rainfall in the preceding 12 -hour period, having at least $0.254 \mathrm{~mm}$ of rainfall in the succeeding 12-hour period such that the total rain for the event was greater than 0.508 $\mathrm{mm}$. There was also a 24-hour inter-event period. All discharge from the roofs was considered part of the current storm event until the start of the next storm event and thus certain storms had to be combined. All runoff flows under $0.04 \mathrm{~L} / \mathrm{s}$ were removed to adjust for baseline due to instrument noise from the flow meters readings standing water as flow.

Storm duration, storm intensity, and antecedent dry period were calculated for each storm event. Precipitation input volume was found by multiplying the precipitation depth found for each storm event by the surface area of both the conventional roof and the ecoroof. Runoff discharge output was found by multiplying the flow at each averaged 5-minute interval, multiplying it by the time between each interval and then binning them per storm event. Roof retention for both roofs was calculated for each storm and in total, 
taking the precipitation input volume, subtracting the runoff volume, divided by the precipitation input volume, and then multiplying by 100 (see Equation.1).

Equation 1:

(Precipitation Depth*Roof Surface Area-Discharge) * 100\%= Retention

The average air temperature, relative humidity, and wind speed from the weather station were also calculated for each storm event.

The total loads of metals and nutrients in the runoff of the roofs per storm event were determined via integration and then added together for the sample period (see Equation 2). There were two storms where we did not collect samples. To account for this, we found the average concentration of each chemical over the entire sampling period to estimate the event runoff concentration following the methods of Van Seters et al. (2009). It is important to note that unit area loading for nutrients were only available for 17 out of 27 storm events.

Equation 2:

Unit Area Load $=\sum$ (Concentration * Flow * Change in Time / Roof Surface Area)

For each chemical, the conventional roof unit area load was subtracted by the ecoroof unit area load to observe the net differences between both roof types (see Equation 3).

Equation 3:

Conventional Unit Area Load - Ecoroof Unit Area Load = Difference in Unit Area Load 
Input from bulk deposition was determined by taking the concentration found from each collector multiplied by the amount of water captured, dividing those values by the surface area of the collector and then averaging the three collectors from that collection period (see Equation 4). If load results from one of the collectors for a given sampling period were extremely different from the other collectors' load values, meaning over 100 percent different, then results from that collector were discarded before averaging for that sampling period. Finally, the averaged loads from each sampling period were added together to give an overall estimate for the study duration. Discharge and unit area loads were normalized by the surface area of each roof. Bulk deposition of nutrients was not determined due to sample preservation methods. Equation 4:

Bulk Deposition Concentration * Volume of Water in Collector / Roof Surface Area $=$ Bulk Deposition Unit Area Load

We compared the conventional roof and ecoroof in terms of runoff discharge, and unit area load per storm. Our alpha values were 0.1 for all statistical tests used. All data was tested for normality using the Shapiro-Wilks test. Equal variance was tested using the F-test of equality of variances. Auto-correlation was tested using the Durbin-Watson test, and if it failed the test, the data was analyzed with a partial-autocorrelation function.

The data was non-normally distributed and generally with unequal variance, even with log transformation. To look at how hydrology (discharge and retention), and metal unit area load runoff per storm between the two roofs were analyzed using a principal component analysis (PCA). This data ordinates the storms from both roofs which allows us to see the similarities and differences between the two systems. The data was scaled 
and centered as well. A broken-stick model was used to determine how many principal component axes to interpret.

To test the differences between the discharge and unit area loads of metals and nutrients between the two roof types a Welch Two Sample T-test was used.

To look at what environmental variables affect roof storm retention and orthophosphate unit area loads multivariate linear regressions were utilized. Multivariate linear regressions were performed on retention and $\mathrm{PO}_{4}{ }^{-3}$. The response variables were transformed using a Box-Cox transformation, the full model was created and checked for multicollinearity. The full models were reduced using a stepwise function and the residuals were tested for normality and equal variance. Finally, the full and reduced models were compared using an ANOVA. Retention was analyzed using a multivariate linear regression with storm length, storm intensity, air temperature, relative humidity, and antecedent dry period as predictor variables. $\mathrm{PO}_{4}^{-3}$ was analyzed with precipitation, antecedent dry period, storm length, storm intensity, air temperature, and wind speed as predictor variables. 


\section{Results}

Storms

A total of 30 storms were sampled from September 2018 through May 2019.

During this period, total rainfall was about $577 \mathrm{~mm}$, with an average of $21.4 \mathrm{~mm}$ of rain per event (Figure 11).

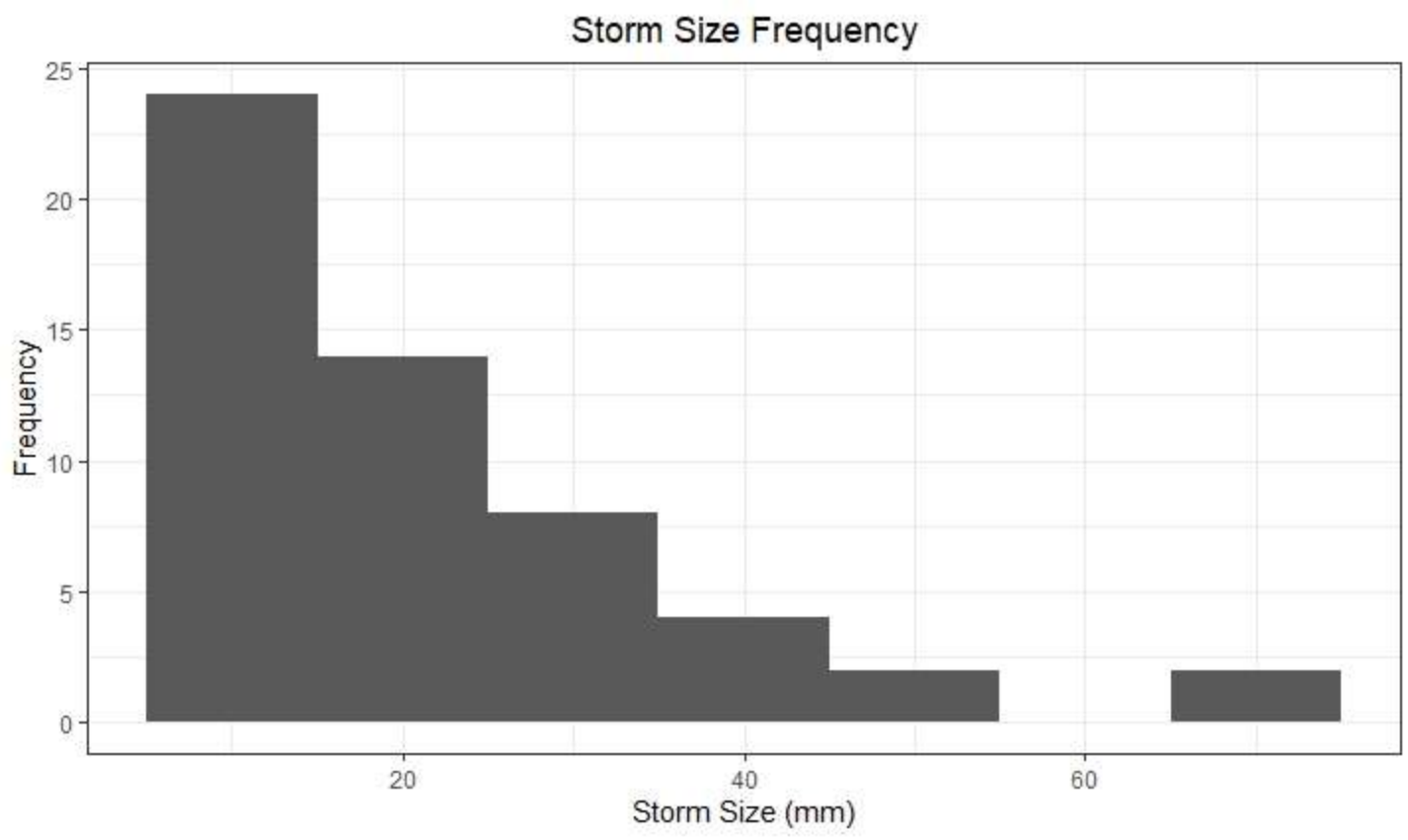

Figure 11. The histogram of the precipitation events over the sampling period over both roofs organized in $10 \mathrm{~mm}$ bins.

The approximate antecedent dry period ranged from 1.1 to 21.5 days, with an average of 2.9 days. The storm length ranged from about 39 hours to about 27 days straight. The average air temperature during storm events ranged from 0.8 to 15.9 degrees $\mathrm{C}$ (Appendix $\underline{A})$. 
Hydrology

Discharge from the conventional roof totaled about 755,153 L of runoff over the sampling period, ranging from about $7785 \mathrm{~L}$ to $96,305 \mathrm{~L}$ of runoff per storm event (Figure 12). The ecoroof totaled about $491,387 \mathrm{~L}$ of runoff with a range of $0 \mathrm{~L}$ to 73,040 $\mathrm{L}$ of runoff per storm event. The average retention of the ecoroof across all storm events was $29 \%$ and the total retention during the sampling period was about $38 \%$.
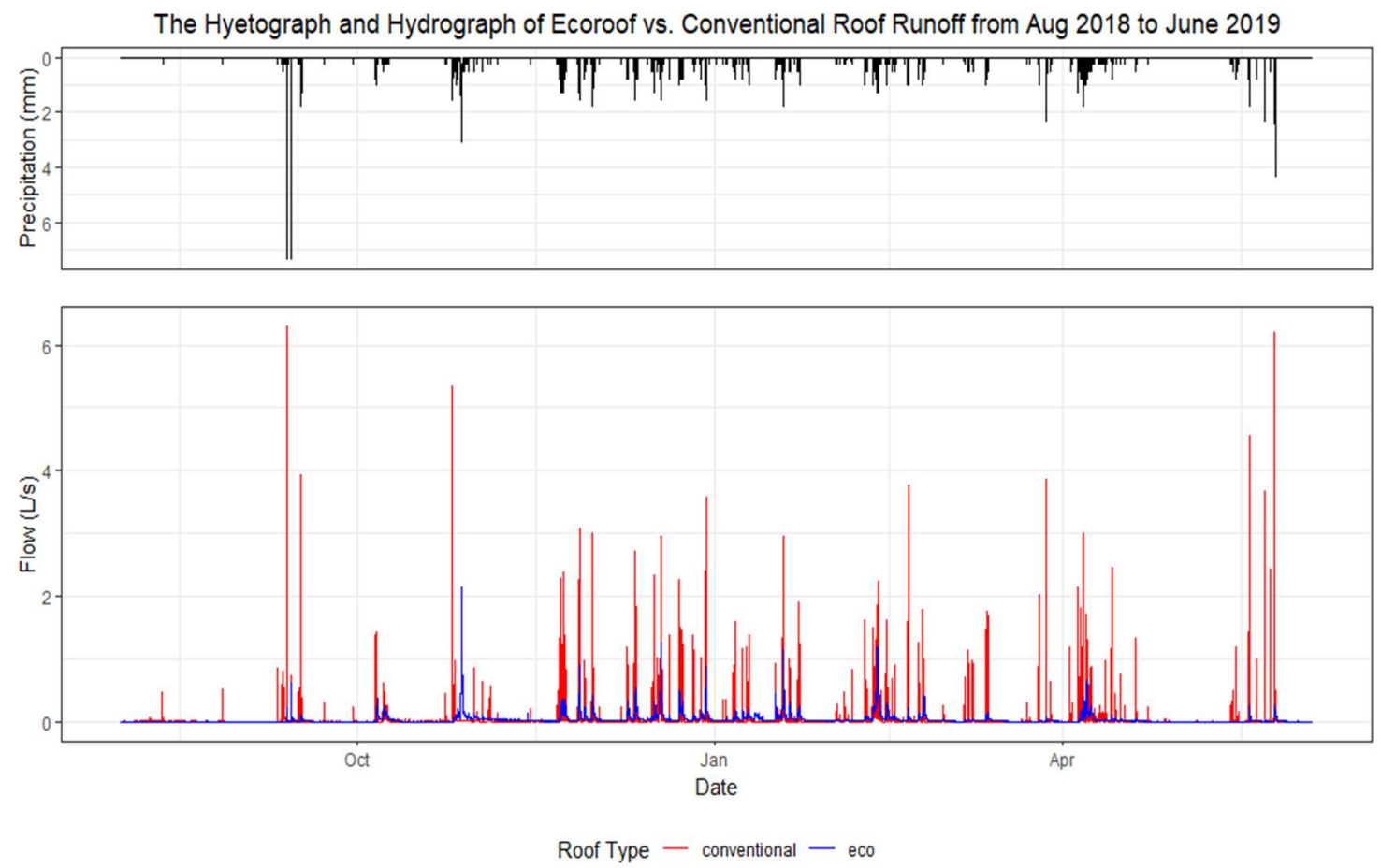

Figure 12. The hyetograph and hydrograph of the conventional roof and ecoroof over the sampling period.

Runoff Chemistry

Overall, 122 samples were collected from the conventional roof and 83 were collected from the ecoroof ( $\underline{\text { Appendix B }})$. Over the sampled storms, 112 samples were 
captured on the conventional roof, with an average of about 4 samples per storm. There were 65 samples captured during the storms of the ecoroof, with an average of about 2.4 samples per event.

The chemical concentrations tend to show hysteresis over the year, with higher concentrations near the beginning of the water year (defined as October to September), for both roofs and decreasing through the rest of the year (Figure 13). $\mathrm{NO}_{3}{ }^{-}$has a different trend from other chemicals, decreasing as the water year starts and then increasing again around spring time for the ecoroof. The ecoroof also appears to have an increase in $\mathrm{PO}_{4}{ }^{-3}$ and $\mathrm{NO}_{3}{ }^{-}$concentrations during spring time.

Appendix $C$ presents the mean, median, and range concentrations from the runoff chemistry of the ecoroof and conventional roof. Several metals (As, Cd, Co, Cr, Mo, Ni, $\mathrm{Pb}, \mathrm{Ti}$, and $\mathrm{V}$ ) were present at extremely low concentrations with maximum concentrations less than $15 \mathrm{ppb}$. Al, B, Ba, Cu, Mn, and Sr had maximum concentrations of $400 \mathrm{ppb}$ or less. The metals with the highest concentrations were $\mathrm{Fe}, \mathrm{Mg}, \mathrm{Na}$, and $\mathrm{Zn}$, with maximum concentrations higher than $400 \mathrm{ppb}$. Concentrations of $\mathrm{Al}, \mathrm{As}, \mathrm{B}, \mathrm{Cr}, \mathrm{Cu}$, $\mathrm{Mg}, \mathrm{Na}, \mathrm{Sr}, \mathrm{Ti}, \mathrm{V}$ were higher in the ecoroof. Concentration of $\mathrm{Al}, \mathrm{Cr}, \mathrm{Fe}$, and $\mathrm{Zn}$ started off higher in the beginning of the sampling period. 


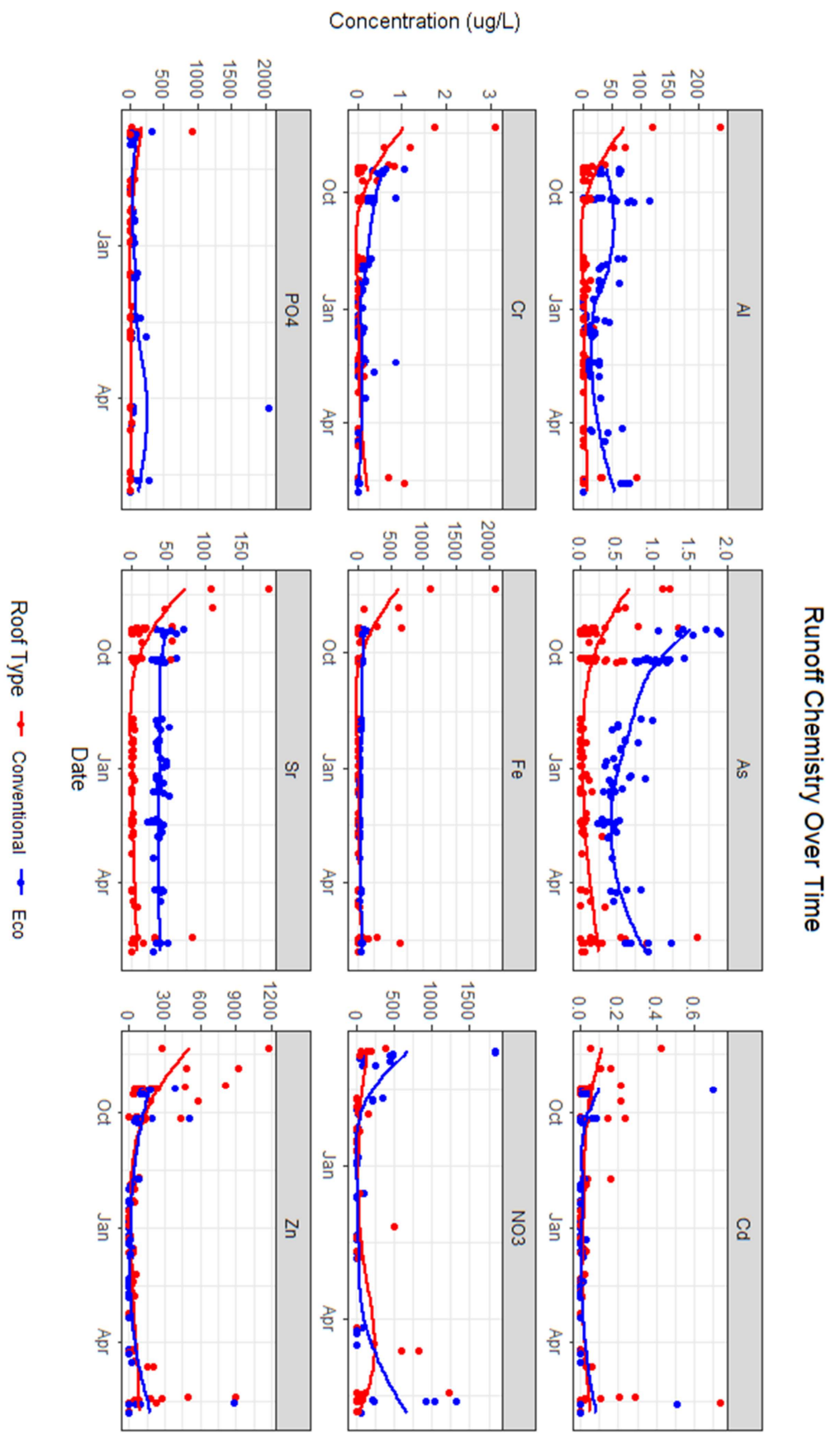

Figure 13. The roof stormwater runoff concentrations of select metals and nutrients of ecological importance, or with an established in-stream water quality standard, criteria, or benchmark, from the conventional roof (red), and ecoroof (blue), over the entire sampling period. 


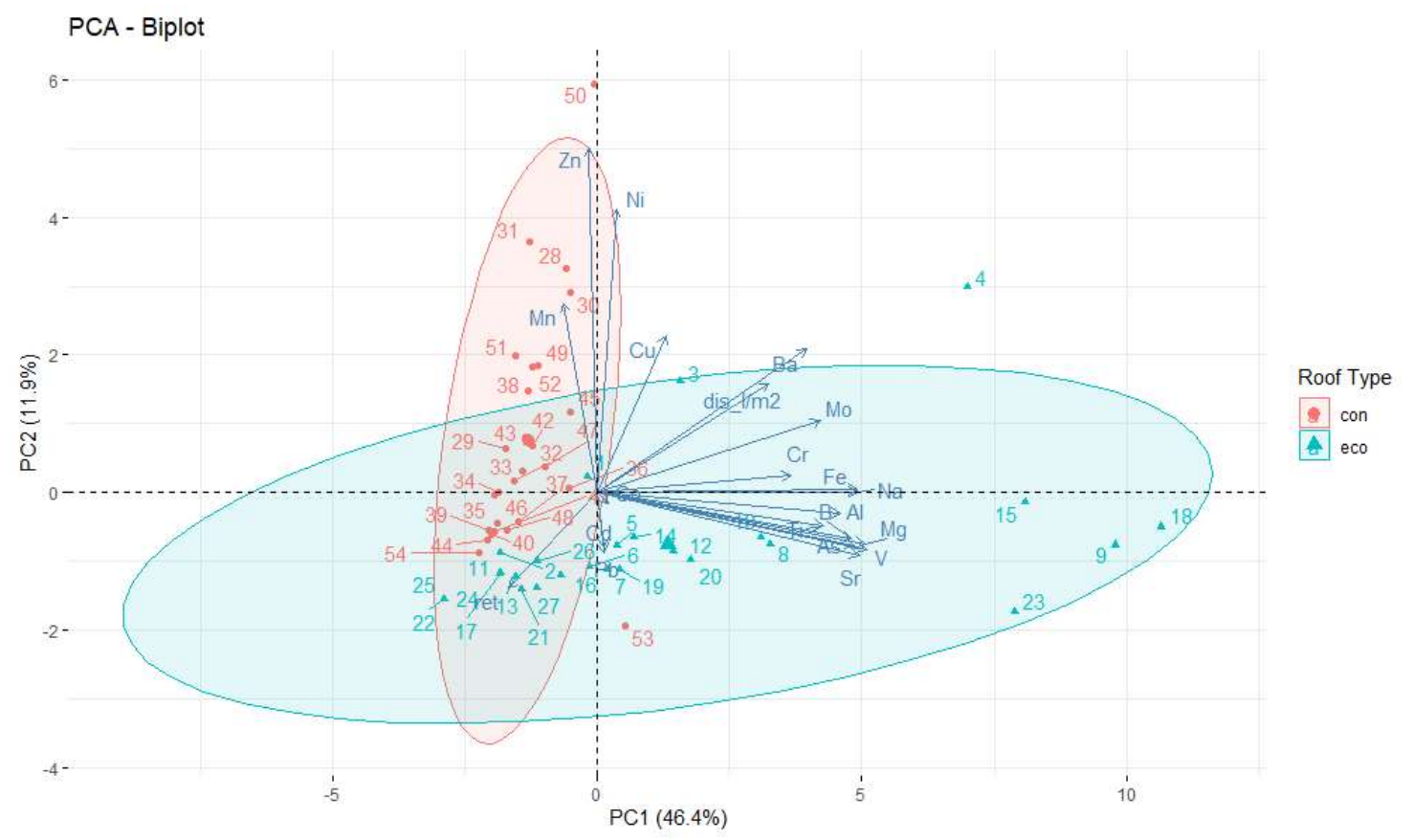

Figure 14. The Principal Component Analysis of ecoroof hydrology and unit area loads over the 27 storm events.

The results of the PCA with the metals, discharge, and retention variables are presented in Figure 14. The broken-stick model results determined that we can only interpret the first principal component (PC1). PC1 explained about 46 percent of the variation in the response variables $(\underline{\text { Appendix } D})$. As less than half the variation in the data can be explained by the PCA, this suggests a large amount of natural noise and variance in these response variables. The main drivers of the variation between the roof types in PC1 are soil metals and cations such as V, Mg, Sr, Na, Fe, As, B, and Al (Appendix E). The storms from the conventional roof tend to be more closely clustered together suggesting that they tend to be more similar to each other throughout the year, while the ecoroof storms tend to be more variable. There also is an overlap between the two groups, suggesting both roofs tend to act similar to each other overall often. 
$\underline{\text { Appendix } F}$ presents the total, mean, median, and range of the metal and nutrient loads from the runoff of both roofs. The chemicals $\mathrm{Al}, \mathrm{As}, \mathrm{B}, \mathrm{Ba}, \mathrm{Cd}, \mathrm{Fe}, \mathrm{Mg}, \mathrm{Mn}, \mathrm{Na}$, $\mathrm{PO}^{-3}, \mathrm{Sr}, \mathrm{Ti}, \mathrm{V}$, and $\mathrm{Zn}$ are statistically significantly different for each $\operatorname{roof}(\mathrm{p}<0.1)$. Al, As, B, Fe, Na, Sr, Ti, and V tend to be higher in the ecoroof compared to the conventional roof. $\mathrm{Ba}, \mathrm{Cd}, \mathrm{Mn}$, and $\mathrm{Zn}$ are higher in the conventional roof.

Analysis of Environmental and Roof Variables

The results of the multivariate linear regression show that retention is significantly negatively related to storm intensity and positively related to air temperature, suggesting that seasonality and storm size are important predictor variables $\left(\right.$ Adj. $\left.R^{2}=0.5266, p<0.001\right)$. The multivariate linear regression of $\mathrm{PO}_{4}^{-3}$ shows that precipitation is significantly positively related to the export of nutrients and negatively related to air temperature $\left(A d j . R^{2}=0.69, p<0.001\right)$.

In terms of bulk deposition concentrations and unit area loads inputs $\mathrm{Al}, \mathrm{Fe}$, and $\mathrm{Zn}$ are the largest components of bulk deposition entering the roof system (Appendix G). While the bulk deposition was collected with a different method than the runoff, measuring total rather than dissolved metals, because dissolved $\mathrm{Zn}$ is higher in the runoff of the conventional roof and dissolved $\mathrm{Al}$ and $\mathrm{Fe}$ is higher in the ecoroof runoff relative to the total metal bulk deposition, this shows that each roof can be a source for those metals.

Table 2. The total bulk deposition unit area load of metals entering the ecoroof research site. 
Chemical Mass $(\mathrm{mg} / \mathrm{m} 2)$

\begin{tabular}{|c|r|}
\hline $\mathbf{B}$ & 0.10 \\
\hline $\mathbf{N a}$ & 21.47 \\
\hline $\mathbf{M g}$ & 4.94 \\
\hline $\mathbf{A l}$ & 4.72 \\
\hline $\mathbf{T i}$ & 0.15 \\
\hline $\mathbf{~}$ & 0.02 \\
\hline $\mathbf{C r}$ & 0.04 \\
\hline $\mathbf{M n}$ & 0.42 \\
\hline $\mathbf{F e}$ & 8.11 \\
\hline $\mathbf{C o}$ & 0.03 \\
\hline $\mathbf{N i}$ & 0.05 \\
\hline $\mathbf{C u}$ & 0.28 \\
\hline $\mathbf{Z n}$ & 3.57 \\
\hline $\mathbf{A s}$ & 0.01 \\
\hline $\mathbf{S r}$ & 0.12 \\
\hline $\mathbf{M o}$ & 0.01 \\
\hline $\mathbf{C d}$ & 0.00 \\
\hline $\mathbf{B a}$ & 0.29 \\
\hline $\mathbf{P b}$ & 0.06 \\
\hline
\end{tabular}

While not taken at the same time each year, the historic annual analysis of soil media chemistry shows that most of the components of soil media vary throughout the years for chemicals such as $\mathrm{NO}_{3}-\mathrm{N}, \mathrm{NH}_{4}, \mathrm{P}, \mathrm{Ca}, \mathrm{Na}, \mathrm{B}, \mathrm{Cu}, \mathrm{Fe}, \mathrm{Mg}$, and $\mathrm{Zn}$, they have remained relatively steady. $\mathrm{NH}_{3}-\mathrm{N}$ has increased over time (Table 3), while $\mathrm{pH}$, soluble salts, and micronutrients such as $\mathrm{Ca}, \mathrm{K}$, and $\mathrm{Mg}$ have noticeably gone down. 
Table 3. The ecoroof media analysis over 4 years.

\begin{tabular}{|c|c|c|c|c|c|}
\hline 厗 & $\begin{array}{l}\text { 总 } \\
\text { 宫 }\end{array}$ & $\begin{array}{l}\text { Oे } \\
\text { 葛 }\end{array}$ & 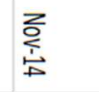 & $\begin{array}{l}\text { 뭉 } \\
\text { 官 }\end{array}$ & 总 \\
\hline जे & के & $\stackrel{\infty}{\rightarrow}$ & $\stackrel{\circ}{\circ}$ & $\stackrel{\infty}{\rightarrow}$ & \\
\hline 古 & 용 & 융 & \& & ๕్జ & 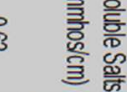 \\
\hline $\begin{array}{l}\omega \\
\ddot{q}\end{array}$ & $\overrightarrow{\mathrm{g}}$ & 앙 & $\omega_{\infty}^{\infty}$ & 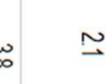 & 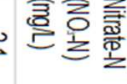 \\
\hline 잉 & 읐 & $\stackrel{\circ}{9}$ & 옥 & 8 & \\
\hline जि & 용 & 요 & $\omega$ & 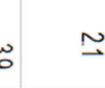 & \\
\hline $\overrightarrow{0}$ & $\overrightarrow{0}$ & 8 & $\vec{\infty}$ & $\vec{v}$ & \\
\hline$\vec{\Phi}$ & $\exists$ & $\widetilde{\widetilde{N}}$ & $\widetilde{O}$ & $\widetilde{ज}$ & \\
\hline or & o & $\vec{\omega}$ & $\approx$ & $\simeq$ & 急言 \\
\hline$\vec{N}$ & $\vec{N}$ & $\vec{\infty}$ & $\vec{\sigma}$ & $\omega$ & \\
\hline or & $\infty$ & $\vec{\omega}$ & $\overrightarrow{\mathrm{v}}$ & or & \\
\hline క్టి & డ్తి & ్ㅐㅇ & 。్తి & 영 & \\
\hline 이 & ¿ & ఉ. & $\stackrel{\circ}{A}$ & ळ & \\
\hline जे & $\stackrel{\infty}{\sim}$ & $\stackrel{9}{\rightarrow}$ & $\vec{\Xi}$ & $=$ & \\
\hline $\overrightarrow{\omega_{\infty}}$ & $\stackrel{\omega}{\sim}$ & $\overrightarrow{\vec{\sigma}}$ & $\tilde{\widetilde{g}}$ & $\overrightarrow{\vec{\omega}}$ & 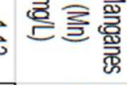 \\
\hline$\omega$ & $\stackrel{\omega}{\omega}$ & $\approx$ & $\omega_{\infty}$ & $\stackrel{\omega}{N}$ & \\
\hline
\end{tabular}

The concentrations of chemicals in the gutter blanks show that $\mathrm{Al}, \mathrm{Cu}, \mathrm{Fe}, \mathrm{Zn}$ are not coming from the gutter materials as those concentrations are essentially $0 \mathrm{ppb}$ (Figure 15). Other chemicals might be contributing to the concentration of the runoff such as As, 
$\mathrm{B}, \mathrm{Ba}, \mathrm{Cd}, \mathrm{Co}, \mathrm{Mg}, \mathrm{Mn}, \mathrm{Mo}, \mathrm{Na}, \mathrm{Sr}, \mathrm{Ti}$, and V. However, it is important to note that while we used the same hose and water source for both roofs, we did not use DI water and thus the water itself might contribute to the noise in the data.

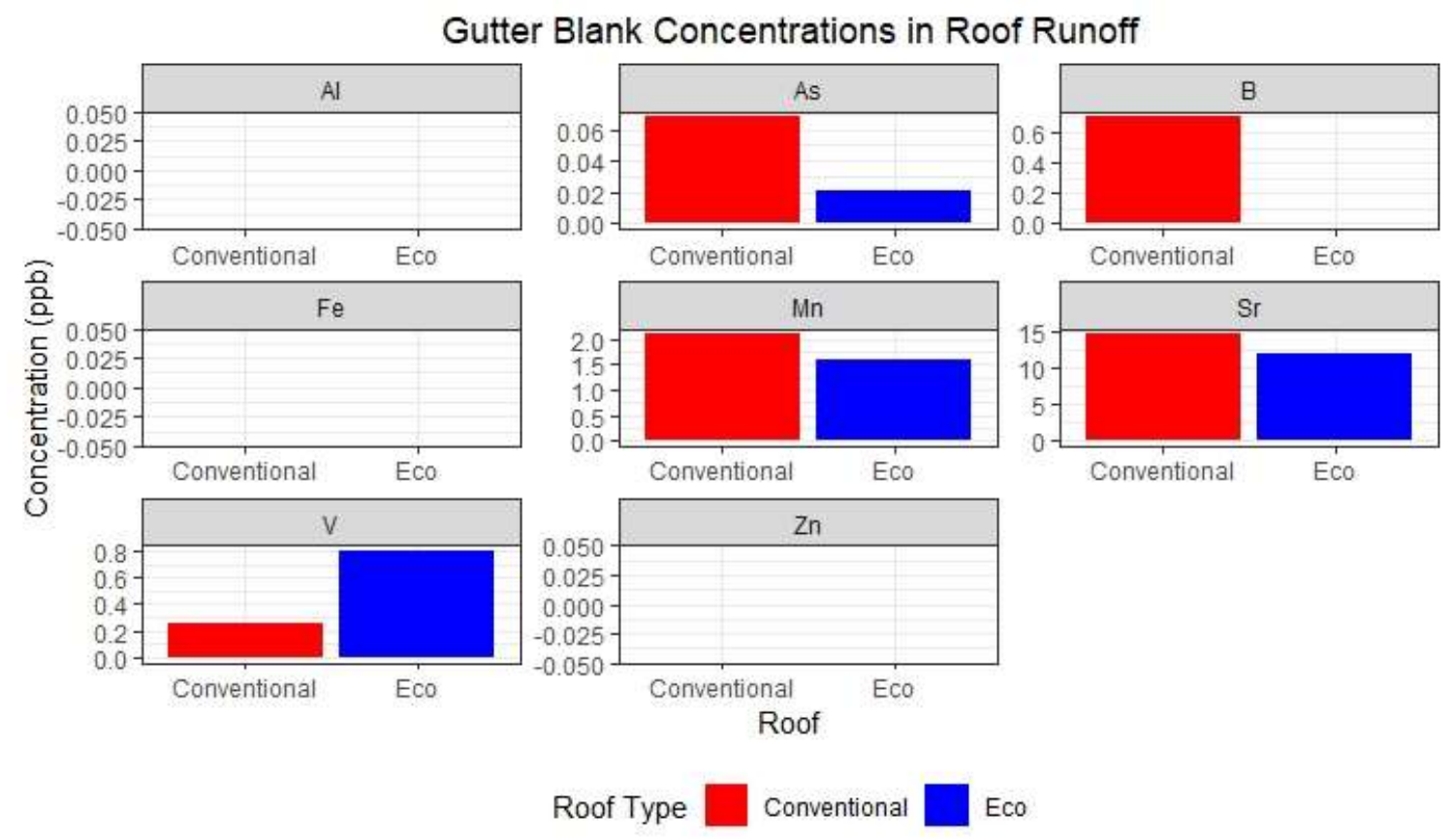

Figure 15. The metal runoff concentrations from the gutter testing from the ecoroof and conventional roof. 


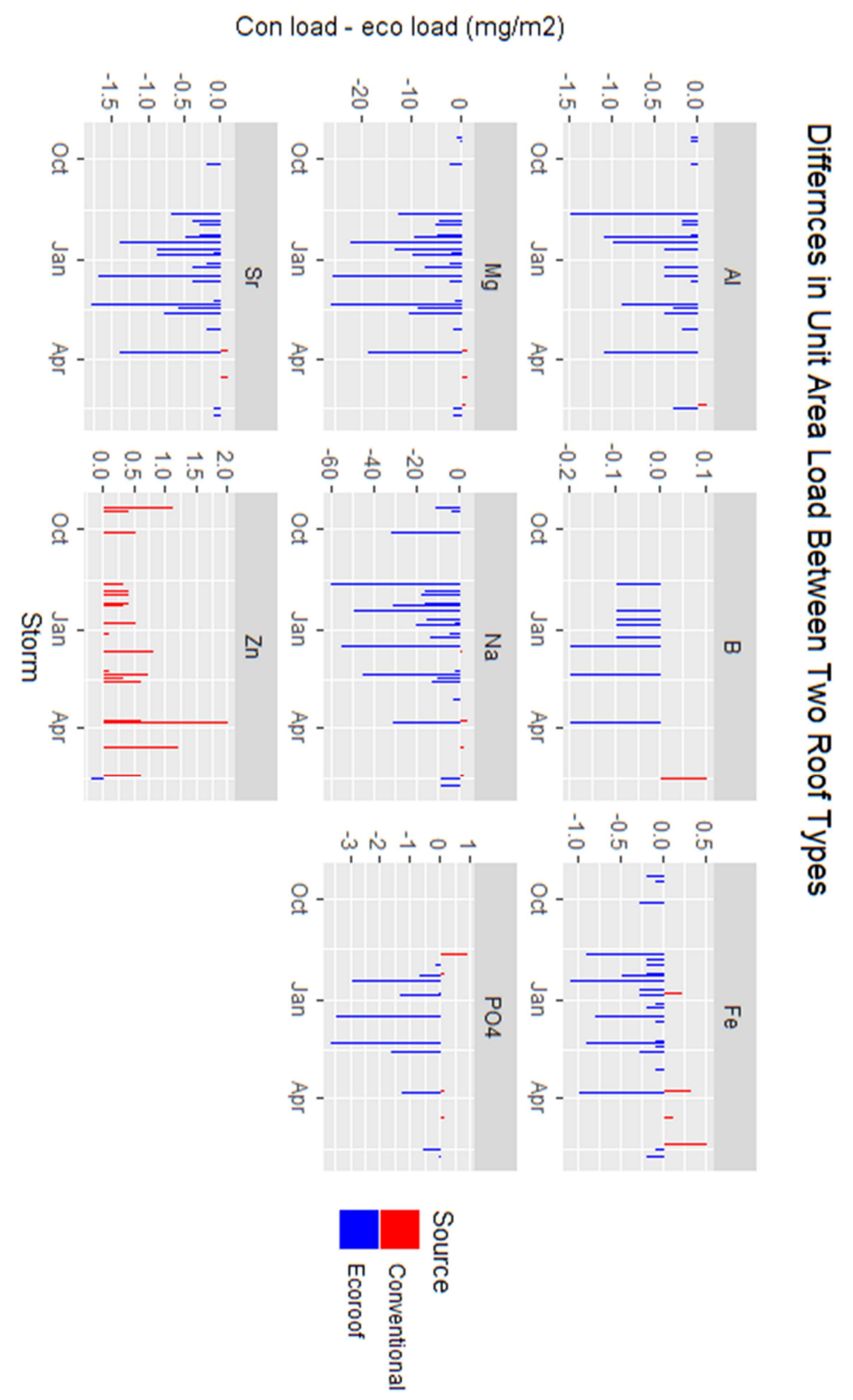

Figure 16. The difference between the unit area loads of metals and nutrients of the conventional roof over the sampling period. Above 0 shows when the conventional roof has higher unit area loads compared to the ecoroof and below 0 shows when the ecoroof has higher unit area loads compared to the conventional roof. 
Looking at the difference of unit area load between the conventional roof and ecoroof over time shows that the levels of $\mathrm{Al}, \mathrm{B}, \mathrm{Fe}, \mathrm{Mg}, \mathrm{Na}, \mathrm{PO}_{4}{ }^{-3}$ and $\mathrm{Sr}$ are higher than in the ecoroof while $\mathrm{Zn}$ is higher in the conventional roof (Figure 16). 


\section{Discussion}

Through the course of the sampling period, there was overlap in the hydrological and chemical behavior of the ecoroof and the conventional roof. The ecoroof runoff tends to be chemically more variable throughout the year.

\section{Hydrology}

In terms of hydrology, there tends to be less runoff from the ecoroof compared to the conventional roof statistically, and retention rates are higher. The retention rates for this roof (an average of $29 \%$ and total of $38 \%$ ) are close to the $23.2 \%$ retention rate found in a past hydrological study on the same roof, suggesting the roof has maintained hydrological performance since 2013 (Schultz et al. 2018). It is important to note that because the flow data for the month of October 2019 was not used for both roofs this affects our total retention value, but not likely the average retention rate per storm event. Past research from Schultz et al. (2018) found that October contributes as much runoff as the beginning of the winter months.

Factors that tend to affect retention rates are air temperature, a proxy for seasonality and how that affects evapotranspiration rates, and storm intensity. A study from Corvallis, Oregon, found similar results with test plots (Schroll et al. 2011). They found the lowest retention during the rainy winter months and highest retention during the summer. In the dry months, they found the test plots with vegetation had higher retention levels compared to the control. Both studies suggest that for smaller storm events, the vegetation helps retain water. 
Finally, in addition to providing retention of precipitation, this facility was shown to reduce peak flows from runoff events. An independent analysis of the ecoroof hydrology performed by Portland BES shows that peak flow reduction ranges from $38 \%$ to $98 \%$ (Aiona, Personal communication, February $19^{\text {th }}, 2020$ ).

\section{Chemistry}

In terms of runoff quality from both roofs, metal concentrations tend to be higher near the beginning of the water year, and decline through the water year. The higher concentrations of such chemicals as $\mathrm{Fe}, \mathrm{Pb}$, and $\mathrm{Zn}$ in the beginning of the water year might be due to the climate of the Pacific Northwest where it does not rain much in the summer, and thus materials deposited from the atmosphere tend to accumulate.

$\mathrm{Al}, \mathrm{As}, \mathrm{B}, \mathrm{Mg}, \mathrm{Na}, \mathrm{Sr}, \mathrm{Ti}, \mathrm{V}$ concentrations were consistently higher in the ecoroof in general. Higher concentrations of $\mathrm{Al}$ from the ecoroof relative to the conventional roof were consistent with results found by Zhang et al. (2015). High levels of micronutrients such as $\mathrm{Mg}$ and $\mathrm{Na}$ were also found by Vijayaraghavan et al. (2012). Concentrations of $\mathrm{NO}_{3}{ }^{-}$and $\mathrm{PO}_{4}{ }^{-3}$ dipped down as winter approached and plants died and then increased up again with the spring blooming of plants and microbial remobilization, which was also suggested by Buffam et al. (2016).

Comparing these ecoroof runoff concentrations to street-level influent and effluent concentrations from street level bioretention facilities in Portland, Oregon, allows us to put these concentrations in context. Mean concentrations of dissolved Zn are higher from both ecoroof and conventional roof compared to both the street level facility influent and effluent (Kohlsmith 2019). Ecoroof runoff concentrations of dissolved $\mathrm{Cu}$ 
were slightly higher than both the street level influent and effluent. It is important to note that ecoroof $\mathrm{PO}_{4}^{-3}$ and $\mathrm{NO}_{3}{ }^{-}$were lower than the effluent from the street level bioretention facilities.

In terms of water quality standards in Oregon, there are no established metrics for urban stormwater from the Oregon Department of Environmental Quality (DEQ). However, the 1200-Z general permit from DEQ for industrial stormwater which provides water quality benchmarks for total $\mathrm{Cu}$, total $\mathrm{Zn}$, total $\mathrm{P}$, and $\mathrm{N}$ as $\mathrm{NO}_{3}-\mathrm{NO}_{2}$ is useful for putting our runoff values into perspective. Additionally, dissolved As, dissolved Ni, dissolved $\mathrm{Pb}$, dissolved $\mathrm{Cd}$, dissolved $\mathrm{Zn}$, and total $\mathrm{Fe}$ in-stream aquatic life chronic water quality standards were estimated utilizing 10 years of hardness values from the Columbia Slough ( $\underline{\text { Table 4 }})$. While both standards do not apply to urban stormwater, and our concentrations are only the dissolved portion of the total metal, they provide a point of reference.

Table 4. The percent of samples collected from the conventional roof and ecoroof that exceed the DEQ 1200-z permit. Permit values were total concentrations while runoff samples were dissolved concentrations.

\begin{tabular}{|l|r|r|r|}
\hline & \multicolumn{3}{|c|}{ \% Exceedance of samples } \\
\hline Chemical & mg/L & Con roof \% Exceedance & Ecoroof \% Exceedance \\
\hline total Cu & 0.02 & 6.56 & 6.02 \\
\hline total Zn & 0.24 & 9.02 & 3.61 \\
\hline Total P & 0.16 & 1.43 & 8.47 \\
\hline NO3-NO2 N & 0.68 & 2.86 & 8.47 \\
\hline
\end{tabular}


From the standpoint of the 1200-z permit, the dissolved concentrations from both roofs are under 10 percent exceedance compared to the total concentration parameters (Table 5

Table 5. The percent of samples collected from the conventional roof and ecoroof that exceed DEQ in-stream aquatic chronic water quality standards. Water quality standard values were dissolved concentrations, excluding $F e$, while runoff samples were dissolved concentrations

\begin{tabular}{|l|r|c|r|}
\hline & \multicolumn{4}{|c|}{ \% Exceedance of samples } \\
\hline Chemical & Aquatic chronicwqs (ppb) & Conventional & Ecoroof \\
\hline Cd & 0.21 & 4.9 & 2.4 \\
\hline Total Fe & 1000.00 & 1.6 & 0.0 \\
\hline Zn & 97.01 & 21.3 & 13.3 \\
\hline
\end{tabular}

From the standpoint of standards for dissolved $\mathrm{As}, \mathrm{Ni}$, and $\mathrm{Pb}$ standards, there were no concentration exceedances. Dissolved $\mathrm{Cd}$ and total Fe were under 5 percent exceedance for both roofs. However, $\mathrm{Zn}$ for both roofs were above 10 percent exceedance.

In terms of runoff unit area loading, which is important to look at as it accounts for both runoff flow and concentration, the conventional roof had significantly higher levels of $\mathrm{Zn}, \mathrm{Mn}$, and $\mathrm{Cd}$, while the ecoroof tended to retain these metals. The $\mathrm{Zn}$ might be due to galvanized roof material to prevent rusting (Thomas and Greene 1993). Van Seters et al. (2009) also found higher unit area loads of $\mathrm{Zn}$, and $\mathrm{Cd}$ runoff from a conventional roof. 
The ecoroof runoff had significantly higher loads of Al, As, B, Ba, Cr, Fe, Mg, $\mathrm{Na}, \mathrm{Sr}, \mathrm{Ti}$, and $\mathrm{PO}_{4}^{-3}$ compared to the conventional roof, which can be attributed to the media and the plants on them. When comparing to the unit area loading results of Van Seters et al. (2009), the same relative relationship was found between ecoroof and conventional roof for $\mathrm{PO}_{4}^{-3}, \mathrm{Ba}$, and $\mathrm{Sr}$. There is a lot of disagreement between this study and those two studies showing the high variability in water quality concentration and unit area loadings.

Ecologically, the ecoroof retains chemicals that have been shown to be correlated with fish embryonic developmental symptoms and mortality such as $\mathrm{Cd}$ and $\mathrm{Zn}$ (McIntyre et al. 2014). However, in regard to ecoroof runoff sources, higher levels of Al in water have been shown to cause a decrease in the activity of certain fish and increased mortality as well (Poleo et al. 1997). The excess $\mathrm{PO}_{4}{ }^{-3}$ is an important chemical to pay attention to in the future as it can contribute to eutrophication and other water quality issues downstream (Khan and Ansari 2005).

\section{Environmental and roof variables}

The second objective of this study was to see the role of environmental and roof variables and how they affect ecoroof runoff chemistry. This was important to help explain the higher level of variability in water quality concentrations and unit area loadings.

The conventional roof is a source of $\mathrm{Zn}$, while the ecoroof retains this metal. This is verified from the bulk deposition collector loadings, as the load leaving the 
conventional roof runoff is higher than the loading coming in from the atmosphere. The gutter blank samples show that there is no contribution of $\mathrm{Zn}$ by gutters to the runoff. $\mathrm{Zn}$ has been a known concern in conventional roof runoff, backed by studies by Okita et al. (2018) and Deshmukh (2019) which also found similar results.

While the ecoroof is located relatively close to a freeway and airport, those areas appear to be far enough to not negatively impact water quality, as bulk deposition concentrations appear to be far lower than catchments in Los Angeles (Sabin et al. 2005; Karner et al. 2010). For analytes with significantly higher unit area loads in ecoroof runoff compared to the bulk deposition values, it is clear that the ecoroof is the source of those metals, as the runoff loadings are higher than the bulk deposition loading. The longterm analysis of ecoroof media shows that the growth media $\mathrm{pH}$ is decreasing over time which might explain the release of soil cations and metals like $\mathrm{Al}$ and $\mathrm{Fe}$ from the ecoroof (Bolan et al. 2003). Additionally, metals like Al and Fe appear to be more naturally abundant in the media, as opposed to $\mathrm{Zn}$, and that would explain the levels coming off the roof.

The gutter blank samples also show that while there is no contribution of the gutter material to $\mathrm{Al}, \mathrm{Cr}, \mathrm{Cu}, \mathrm{Fe}, \mathrm{Ni}, \mathrm{Zn}$, and $\mathrm{Pb}$ concentrations, the gutter material might be a source for $\mathrm{As}, \mathrm{B}, \mathrm{Ba}, \mathrm{Cd}, \mathrm{Co}, \mathrm{Mg}, \mathrm{Mn}, \mathrm{Mo}, \mathrm{Na}, \mathrm{Sr}$, Ti, and $\mathrm{V}$. It is important to note that we used water from an irrigation hose instead of DI-water which might skew these results.

$\mathrm{PO}_{4}^{-3}$ is related precipitation and air temperature, a proxy for plants and seasonality. As precipitation increases, $\mathrm{PO}_{4}^{-3}$ may be desorbed and vulnerable to loss. As 
air temperatures increase, there would hypothetically be mobilization and release of nutrients from microbial decomposition. This is also consistent with the fact that nutrient concentrations in runoff are lower in the fall and winter and slowly rise in the spring. These results align with findings in with Buffam et al. (2016), who found similar trends with their study.

\section{Research going forward}

The limitation of this study was that it was only for one water year. Long term monitoring performed in a similar fashion as this study would be important, given that seasonal and annual trends can vary throughout the years. This form of research would build upon the results from this study and help understand and model ecoroof chemical behavior. Another source of improvement in this study would be to measure the total (particulates and dissolved) analytes in the runoff to allow for a more direct mass balance between bulk deposition input, as related studies suggest that total metals can be up to 4.5 times higher than dissolved metals in effluent and influent (Kohlsmith 2019).

Ecoroofs are complex engineered systems but because they are human made, they can be further engineered to reach performance goals. Optimizing ecoroof performance is an important direction for future study into these BMPs. One option for further study is to look more into ecoroof media and media customization. Various substrates have different metal leachate characteristics depending on the material and on the presence of plants (Alsup et al. 2010). There is promising research using drinking water treatment residuals for decreasing phosphorus concentrations (Palmer et al. 2013). Studies by Poor et al. (2018) with mycorrhizae-inoculated growth media showed reductions in total phosphorus 
and copper. Lime and $\mathrm{Ca}$ additions is a technique that has been used in agricultural and natural systems to raise soil $\mathrm{pH}$ (Bolan et al. 2003).

Finally, biochar studies in the field show evidence that certain biochar types help decrease runoff quantity and runoff nutrient concentrations, meaning there is less runoff loading of potentially ecologically harmful chemicals (Kuoppamaki et al. 2015). 


\section{Conclusion}

In summary, ecoroofs are important for reducing the hydrological impacts of the urban landscape on surrounding natural systems. They reduce the amount of impervious surfaces in cities, and offer the ecosystem services of discharge reduction, retention, peak attenuation and lag. This study shows that metals such as $\mathrm{Cd}$ and $\mathrm{Zn}$ were retained in the ecoroof relative to the conventional roof. However, there can be a risk of these systems potentially introducing additional metals that are already naturally occurring at high

concentrations in soil, and nutrients such as $\mathrm{Fe}$, and $\mathrm{Al}$, and $\mathrm{PO}_{4}{ }^{-3}$, into natural waterbodies, contributing to pollution concerns.

Based on our study, there is evidence that the mechanisms for these water quality issues are due to the composition and chemistry of the growing media and seasonal microbial biogeochemical processes. More work is needed to inform the optimization of these systems further with technologies like soil amendments, and resin socks. Finally, ecoroofs might have issues as a standalone stormwater BMP, but are important in systems approaches to urban planning. What matters for ecoroofs is what is downstream. For instance, if the ecoroof drains to a treatment plant, or another stormwater facility as part of a greater treatment train, then ecoroofs are a wonderful tool. 


\section{References:}

Aiona, Adrienne. (2020). Portland Bureau of Environmental Services. Email Correspondence.

Alsup, S., Ebbs, S., \& Retzlaff, W. (2010). The exchangeability and leachability of metals from select green roof growth substrates. Urban Ecosystems.

Anim, D. O., Fletcher, T. D., Vietz, G. J., Pasternack, G. B., \& Burns, M. J. (2018). Effect of urbanization on stream hydraulics. River Research and Applications.

Arnold Jr, C. L., \& Gibbons, C. J. (1996). Impervious surface coverage: the emergence of a key environmental indicator. Journal of the American Planning Association, 62(2), 243-258.

Auguie Baptiste (2015). gridExtra: Miscellaneous Functions for "Grid" Graphics. R package version 2.0.0. http://CRAN.R-project.org/package=gridExtra

Bolan, N. S., Adriano, D. C., \& Curtin, D. (2003). Soil acidification and liming interactions with nutrient and heavy metal transformation and bioavailability. Advances in agronomy, 78(21), 5-272.

Buffam, I., Mitchell, M. E., \& Durtsche, R. D. (2016). Environmental drivers of seasonal variation in green roof runoff water quality. Ecological Engineering, 91, 506-514.

Carpenter, S. R., Caraco, N. F., Correll, D. L., Howarth, R. W., Sharpley, A. N., \& Smith, V. H. (1998). Nonpoint pollution of surface waters with phosphorus and nitrogen. Ecological applications, 8(3), 559-568.

City of Portland. (n.d). Central City 2035 Volume 2A Zoning Code and Map Amendments Part 1: Central City Plan District. [Date accessed: August 21, 2018]. [Url: https://www.portlandoregon.gov/bps/article/689695].

Bureau of Environmental Services (BES), City of Portland. (2013). Stormwater Managment Facility Monitoring Report. [Url: https://www.portlandoregon.gov/bes/article/563749]

Deshmukh, Pranoti P., "Water Quality Analysis of Ecoroof Runoff in Portland" (2019). Civil and Environmental Engineering Master's Project Reports. 48.

Dietz, M. E. (2007). Low impact development practices: A review of current research and recommendations for future directions. Water, air, and soil pollution, 186(14), 351-363.

Grimm, N. B., Faeth, S. H., Golubiewski, N. E., Redman, C. L., Wu, J., Bai, X., \& Briggs, J. M. (2008). Global change and the ecology of cities. science, 319(5864), 756-760.

Grolemund G, Wickham H (2011). "Dates and Times Made Easy with lubridate." Journal of Statistical Software, 40(3), 1-25. http://www.jstatsoft.org/v40/i03/.

Jari Oksanen, F. Guillaume Blanchet, Michael Friendly, Roeland Kindt, Pierre Legendre, Dan McGlinn, Peter R. Minchin, R. B. O'Hara, Gavin L. Simpson, Peter Solymos, M. Henry H. Stevens, Eduard Szoecs and Helene Wagner (2019). vegan: Community Ecology Package. R package version 2.5-6. https://CRAN.Rproject.org/package= vegan

Karner, A. A., Eisinger, D. S., \& Niemeier, D. A. (2010). Near-roadway air quality: synthesizing the findings from real-world data. Environmental science \& technology, 44(14), 5334-5344. 
Kassambara Alboukadel and Mundt Fabian (2019). factoextra: Extract and Visualize the Results of Multivariate Data Analyses. R package version 1.0.6. https://CRAN.Rproject.org/package=factoextra

Khan, F. A., \& Ansari, A. A. (2005). Eutrophication: an ecological vision. The botanical review, 71(4), 449-482.

Kohlsmith, Emma R. (2019). Stormwater Treatment Effectiveness of Established Bioretention Facilities in Portland, Oregon Dissertations and Theses. Paper 5176.

Kuoppamäki, K., Hagner, M., Lehvävirta, S., \& Setälä, H. (2016). Biochar amendment in the green roof substrate affects runoff quality and quantity. Ecological Engineering, 88, 1-9.

Lin Thomas, Nicolae Berendea, and François Romain (2020). farver: High Performance Colour Space Manipulation. R package version 2.0.2. https://CRAN.Rproject.org/package $=$ farver

McIntyre, J. K., Davis, J. W., Hinman, C., Macneale, K. H., Anulacion, B. F., Scholz, N. L., \& Stark, J. D. (2015). Soil bioretention protects juvenile salmon and their prey from the toxic impacts of urban stormwater runoff. Chemosphere, 132, 213-219.

McIntyre, J. K., Davis, J. W., Incardona, J. P., Stark, J. D., Anulacion, B. F., \& Scholz, N. L. (2014). Zebrafish and clean water technology: Assessing soil bioretention as a protective treatment for toxic urban runoff. Science of the Total Environment, 500, 173-180.

Miller, Charlie. (2019). Roofmeadow. Email Correspondence.

National Centers for Environmental Information (NOAA). (2020.). Daily Summaries Station Details. Retrieved March 6, 2020, [Url:https://www.ncdc.noaa.gov/cdoweb/datasets/GHCND/stations/GHCND:USW00024229/detail]

Okita, J., Poor, C., Kleiss, J. M., \& Eckmann, T. (2018). Effect of green roof age on runoff water quality in Portland, Oregon. Journal of Green Building, 13(2), 4254.

Poléo, A. B., Østbye, K., Øxnevad, S. A., Andersen, R. A., Heibo, E., \& Vøllestad, L. A. (1997). Toxicity of acid aluminium-rich water to seven freshwater fish species: a comparative laboratory study. Environmental Pollution, 96(2), 129-139.

Poor, C., Balmes, C., Freudenthaler, M., \& Martinez, A. (2018). Role of Mycelium in Bioretention Systems: Evaluation of Nutrient and Metal Retention in Mycorrhizae-Inoculated Mesocosms. Journal of Environmental Engineering (United States), 144(6), 1-7.

Paul, M. J., \& Meyer, J. L. (2001). Streams in the urban landscape. Annual review of Ecology and Systematics, 32(1), 333-365.

RStudio Team (2016). RStudio: Integrated Development for R. RStudio, Inc., Boston, MA. [URL http://www.rstudio.com/].

Sabin, L. D., Lim, J. H., Stolzenbach, K. D., \& Schiff, K. C. (2005). Contribution of trace metals from atmospheric deposition to stormwater runoff in a small impervious urban catchment. Water research, 39(16), 3929-3937.

Scholz NL, Myers MS, McCarthy SG, Labenia JS, McIntyre JK, Ylitalo GM, et al. (2011) Recurrent Die-Offs of Adult Coho Salmon Returning to Spawn in Puget Sound Lowland Urban Streams. PLoS ONE 6(12): e28013. 
Schroll, E., Lambrinos, J., Righetti, T., \& Sandrock, D. (2011). The role of vegetation in regulating stormwater runoff from green roofs in a winter rainfall climate. Ecological engineering, 37(4), 595-600.

Speak, A. F., Rothwell, J. J., Lindley, S. J., \& Smith, C. L. (2014). Metal and nutrient dynamics on an aged intensive green roof. Environmental Pollution. https://doi.org/10.1016/j.envpol.2013.08.017

Schultz, I., Sailor, D. J., \& Starry, O. (2018). Effects of substrate depth and precipitation characteristics on stormwater retention by two green roofs in Portland OR. Journal of Hydrology: Regional Studies, 18, 110-118.

Spolek, G. (2008). Performance monitoring of three ecoroofs in Portland, Oregon. Urban Ecosystems, 11(4), 349-359.

Thomas, P. R., \& Greene, G. R. (1993). Rainwater quality from different roof catchments. Water science and technology, 28(3-5), 291-299.

Van Seters, T., Rocha, L., Smith, D., \& MacMillan, G. (2009). Evaluation of green roofs for runoff retention, runoff quality, and leachability. Water Quality Research Journal of Canada.

Vijayaraghavan, K., Joshi, U. M., \& Balasubramanian, R. (2012). A field study to evaluate runoff quality from green roofs. Water research, 46(4), 1337-1345.

Walsh, C. J., Fletcher, T. D., \& Burns, M. J. (2012). Urban stormwater runoff: a new class of environmental flow problem. PLoS One, 7(9), e45814.

Wang, L., Bammler, T. K., Beyer, R. P., \& Gallagher, E. P. (2013). Copper-induced deregulation of microRNA expression in the zebrafish olfactory system.

Environmental science \& technology, 47(13), 7466-7474.

Wickham et al., (2019). Welcome to the tidyverse. Journal of Open Source Software, 4(43), 1686, https://doi.org/10.21105/joss.01686

Wu, L., Jiang, Y., Zhang, L., Chen, L., \& Zhang, H. (2014). Toxicity of urban highway runoff in Shanghai to zebrafish (Danio rerio) embryos and luminous bacteria (Vibrio qinghaiensis. Q67). Environmental Science and Pollution Research, 21(4), 2663-2676.

Zeileis Achim, Hothorn Torsten (2002). Diagnostic Checking in Regression Relationships. R News 2(3), 7-10. URL https:/CRAN.R-project.org/doc/Rnews/

Zhang, Q., Miao, L., Wang, X., Liu, D., Zhu, L., Zhou, B., Sun J., \& Liu, J. (2015). The capacity of greening roof to reduce stormwater runoff and pollution. Landscape and Urban Planning, 144, 142-150. 


\section{Appendix A: Storm summaries}

Table A1. The summary statistics of the 30 storm events over the 10 month sampling

period.

\begin{tabular}{|c|c|c|c|c|c|c|c|c|c|}
\hline \multirow[b]{2}{*}{ gorm } & \multirow[b]{2}{*}{ Start } & \multirow[b]{2}{*}{ End } & \multirow{2}{*}{\multicolumn{2}{|c|}{ Preóp $(\mathrm{mm}$ ) spproximste Dry period (由ys) }} & & con & & {$[\infty$} & \\
\hline & & & & & \multicolumn{5}{|c|}{ svg air temperature $Q$ Dischr g (L) ret ention Dixhsrge (L) Retert ín } \\
\hline & 1 9/11/201808:10 & $9 / 15 / 201817.00$ & 28.7 & 1.1 & 15.5 & 19009.8 & 53.0 & 3427.6 & 90.0 \\
\hline & $29 / 15 / 201817.05$ & $10 / 5 / 20180900$ & 10.2 & 1.3 & 15.9 & 11593.9 & 22.3 & 1516.2 & 87.6 \\
\hline & $310 / 5 / 201809.05$ & $10 / 7 / 201810: 40$ & 14.2 & 3.7 & 110 & 18345.8 & 12.1 & 9235.8 & 45.9 \\
\hline & $511 / 21 / 201810 \cdot 20$ & $11 / 26 / 201815: 50: 00 \mathrm{AM}$ & 27.7 & 4.4 & 7.3 & 381028 & 6.3 & 253448 & 23.7 \\
\hline & $611 / 26 / 201815.55$ & $11 / 30 / 201804: 30$ & 23.6 & 1.7 & 9.7 & 32003.7 & 5.1 & 263925 & 6.9 \\
\hline & $711 / 30 / 201804: 35$ & $12 / 9 / 201810: 30$ & 10.9 & 1.5 & 48 & 13383.7 & 16.5 & 10285.7 & 21.5 \\
\hline & $812 / 9 / 201810: 35$ & $12 / 11 / 201801: 45$ & 13.2 & 1.4 & 3.9 & 18717.6 & 3.5 & 11738.4 & 25.9 \\
\hline & 9 12/11/201801:50 & $12 / 15 / 20182150$ & 16.3 & 1.2 & 8.2 & 22428.2 & 6.0 & 20748.4 & $\cdot 6.4$ \\
\hline & $012 / 15 / 201821.55$ & $12 / 22 / 201817: 15$ & 41.7 & 3.7 & 8.6 & 58507.5 & 4.3 & 49710.3 & 0.6 \\
\hline & 1 12/22/201817:20 & $12 / 26 / 201807: 20$ & 23.4 & 1.3 & 5.9 & 326510 & 48 & 27935.0 & 0.4 \\
\hline & $212 / 26 / 201807 \cdot 25$ & $12 / 27 / 201823: 35$ & 5.8 & 1.5 & 6.5 & 8097.1 & 5.6 & 4976.2 & 29.0 \\
\hline & $312 / 27 / 201823: 40$ & $1 / 5 / 201920005$ & 21.1 & 1.1 & 6.3 & 29239.7 & 5.4 & 23503.2 & 7.1 \\
\hline & $4 \quad 1 / 5 / 201920: 10$ & $1 / 8 / 201903: 15$ & 8.1 & 1.7 & 5.6 & 11033.9 & 7.5 & 6187.8 & 36.6 \\
\hline & $5 \quad 1 / 8 / 201903: 20$ & $1 / 16 / 201917 \cdot 25$ & 13.7 & 1.6 & 6.1 & 20030.4 & 0.5 & 16287.4 & 10 \\
\hline & $61 / 16 / 201917: 30$ & $1 / 21 / 201917: 35$ & 41.9 & 6.4 & 6.6 & 60224.3 & 2.1 & 59382.2 & -18.1 \\
\hline & 1/21/201917:\$0 & $2 / 8 / 20191755$ & 16.0 & 1.1 & 4.7 & 218618 & 6.9 & 101179 & 47.3 \\
\hline & (8) 2/8/2019 18:00 & $2 / 10 / 201921: 10$ & 8.1 & 2.3 & 0.8 & 10160.5 & 148 & 4895.2 & 49.8 \\
\hline 19 & 9 2/10/201921:15 & $2 / 14 / 20190500$ & 51.6 & 1.5 & 5.1 & 730448 & 3.5 & 73039.5 & -180 \\
\hline 20 & (0) 2/14/201905.05 & $2 / 18 / 20191955$ & 15.2 & 1.1 & 40 & 19099.9 & 11.1 & 17803.2 & 2.7 \\
\hline 21 & $12 / 18 / 20192000$ & $3 / 6 / 201910: 30$ & 27.4 & 1.8 & 26 & 348728 & 13.4 & 25759.8 & 21.7 \\
\hline 22.23 & $3 / 6 / 201910: 35$ & $3 / 25 / 20191200$ & 21.844 & 5.2 & 9.9 & 27663.8 & 13.7 & 6683.1 & 74.5 \\
\hline 24 & $43 / 2 / 201912.05$ & $3 / 27 / 20191400$ & 7.6 & 1.9 & 9.8 & 9431.9 & 15.7 & 0.0 & 100.0 \\
\hline 25 and 26 & $3 / 27 / 201914.05$ & $4 / 19 / 201914: 45$ & 73.9 & 1.7 & 11.5 & 96305.3 & 11.2 & 40590.7 & 47.5 \\
\hline 27 & 7 $4 / 19 / 20191450$ & $5 / 14 / 201907: 15$ & 6.6 & 2.6 & 14.5 & 9191.3 & 5.2 & 0.0 & 100.0 \\
\hline 28 & $85 / 14 / 201907: 20$ & $5 / 18 / 20191855$ & 6.6 & 21.5 & 144 & 7734.9 & 19.7 & 0.0 & 100.0 \\
\hline 29 & $95 / 18 / 201919: 00$ & $5 / 24 / 201913: 30$ & 27.7 & 2.4 & 148 & 35086.1 & 13.7 & 4171.3 & 87.4 \\
\hline 30 & (0) $5 / 24 / 201913: 35$ & $5 / 27 / 201900: 00$ & 13.7 & 1.7 & 13.9 & 14729.9 & 26.8 & 5655.0 & 65.6 \\
\hline total & & & 576.8 & & & $7551527^{\prime}$ & 0.1 & 4913872 & 29.0 \\
\hline
\end{tabular}




\section{Appendix B: Sample collection}

The Collection of Samples from the Conventional Roof from Aug 2018 to June 2019

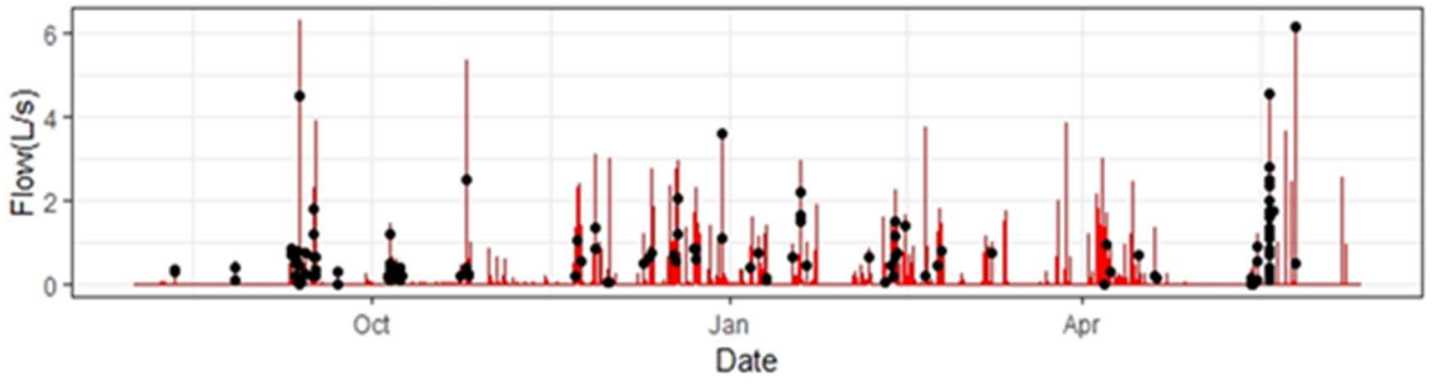

The Collection of Samples from the Ecoroof from August 2018 to June 2019

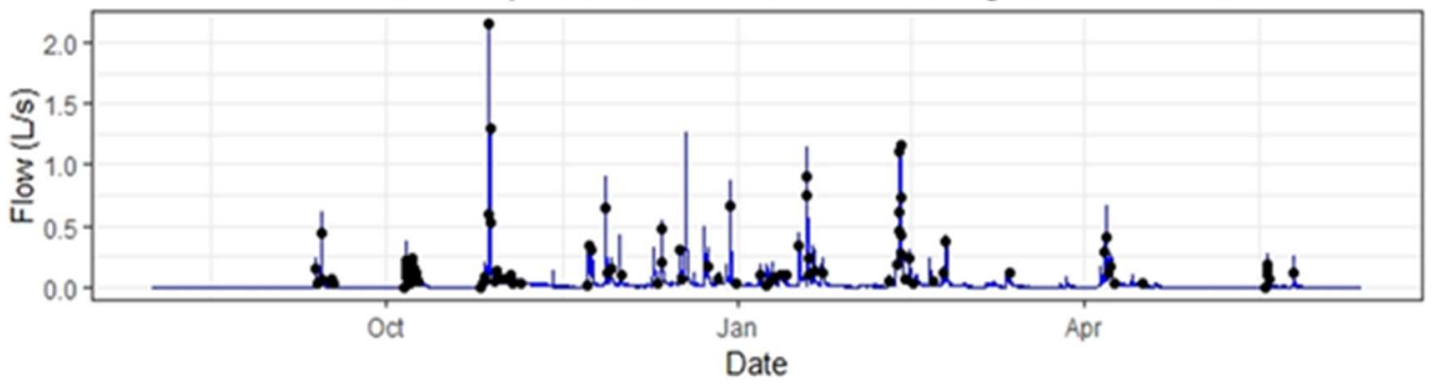

Figure A1. The samples collected from the ecoroof and conventional roof over the sampling period. 


\section{Appendix C: Runoff Concentration Summaries}

Table A2. The mean, median, standard deviation, minimum, and maximum

concentrations values from the runoff of the conventional roof and ecoroof over the

sampling period as well as the gutter blank values from both roofs.

\begin{tabular}{|c|c|c|c|c|c|c|c|}
\hline Chemical & Roof & Mean & Median & Standard I & IMin & $\operatorname{Max}$ & Gutter Blank \\
\hline & Conventional & 7.042068 & 0 & 26.76013 & 0 & 237.0422 & \\
\hline \multirow[t]{2}{*}{ Al } & Eco & 32.30386 & 26.64683 & 26.46159 & 0 & 115.1084 & \\
\hline & Conventional & 0.171 & 0.068909 & 0.274379 & 0 & 1.590804 & 0.068029539 \\
\hline \multirow[t]{2}{*}{ As } & Eco & 0.723511 & 0.61137 & 0.375047 & 0.240964 & 1.917303 & 0.021025552 \\
\hline & Conventional & 2.929865 & 0.226281 & 7.887778 & 0 & 53.16841 & 0.69880543 \\
\hline \multirow[t]{2}{*}{ B } & Eco & 5.90704 & 4.564158 & 4.618162 & 0 & 22.25426 & \\
\hline & Conventional & 25.2414 & 10.07164 & 447.48168 & 0 & 386.3784 & 5.275583018 \\
\hline \multirow[t]{2}{*}{$B a$} & Eco & 12.17344 & 10.98104 & 4.566535 & 6.168346 & 28.83647 & 2. 148291857 \\
\hline & Conventional & 0.031966 & 0 & 0.090367 & 0 & 0.737772 & \\
\hline \multirow[t]{2}{*}{$\mathrm{Cd}$} & Eco & 0.019848 & 0 & 0.093923 & 0 & 0.694135 & 0.05200522 \\
\hline & Conventional & 0.267538 & 0.01217 & 0.753164 & 0 & 4.641637 & 0.081494335 \\
\hline \multirow[t]{2}{*}{ Co } & Eco & 0.188415 & 0.111561 & $1 \quad 0.31388$ & 0 & 2.41182 & 0.310454682 \\
\hline & Conventional & 0.137738 & 0 & 0.402148 & 0 & 3.100478 & \\
\hline \multirow[t]{2}{*}{$\mathrm{Cr}$} & Eco & 0.187739 & 0.124709 & $\begin{array}{l}9 \\
9\end{array} 0.21633$ & 0 & 1.054058 & \\
\hline & Conventional & 3.583429 & 0 & 11.28112 & 0 & 98.66309 & \\
\hline \multirow[t]{2}{*}{$\mathrm{Cu}$} & Eco & 5.925245 & 0 & 8.485179 & 0 & 27.02051 & \\
\hline & Conventional & 52.79383 & 1.276535 & 5235.0591 & 0 & 2094.98 & \\
\hline \multirow[t]{2}{*}{$\mathrm{Fe}$} & Eco & 32.37817 & 26.15929 & 20.52087 & 0 & 121.9751 & \\
\hline & Conventional & 194.5163 & 35.93784 & 4556.0356 & 0 & 4382.345 & 552.5993996 \\
\hline \multirow[t]{2}{*}{$\mathrm{Mg}$} & Eco & 604.7342 & 598.4902 & 2128.4902 & 215.0603 & 1026.281 & 548.2685282 \\
\hline & Conventional & 21.32985 & 0.560766 & 569.63233 & 0 & 395.7219 & 2.098047467 \\
\hline \multirow[t]{2}{*}{$\mathrm{Mn}$} & Eco & 2.915086 & 0.210358 & 817.93801 & 0 & 163.0413 & 1.605636828 \\
\hline & Conventional & 0.260477 & 0.051835 & 0.606112 & 0 & 3.586042 & 0.093178528 \\
\hline \multirow[t]{2}{*}{ Mo } & Eco & 0.255763 & 0.147357 & $7 \quad 0.24985$ & 0 & 1.427642 & \\
\hline & Conventional & 546.1274 & 143.7377 & 7 1419.938 & 0 & 12762.07 & 2981.788452 \\
\hline \multirow[t]{2}{*}{$\mathrm{Na}$} & Eco & 2834.935 & 1919.582 & 22198.905 & 731.7448 & 9882.36 & 2975.873112 \\
\hline & Conventional & 0.68274 & 0 & 2.279616 & 0 & 16.83724 & \\
\hline \multirow[t]{2}{*}{$\mathrm{Ni}$} & Eco & 0.441416 & 0 & 0.652776 & 0 & 2.885384 & \\
\hline & Conventional & 0.044118 & 0 & 0.202175 & 0 & 1.594278 & \\
\hline \multirow[t]{2}{*}{$\mathrm{Pb}$} & Eco & 0.03284 & 0 & 0.109937 & 0 & 0.863262 & \\
\hline & Conventional & 9.657354 & 2.300427 & 724.57992 & 0 & 186.5991 & 14.54722961 \\
\hline \multirow[t]{2}{*}{$\mathrm{Sr}$} & Eco & 38.24862 & 36.99427 & 77.879332 & 23.00313 & 70.24398 & 11.93764976 \\
\hline & Conventional & 0.132454 & 0 & 0.751652 & 0 & 7.323152 & \\
\hline \multirow[t]{2}{*}{$\mathrm{Ti}$} & Eco & 1.397471 & 1.170009 & 9 1.503138 & 0 & 6.539552 & 0.482871278 \\
\hline & Conventional & 0.309048 & 0.11742 & 0.645936 & 0 & 4.940807 & 0.253658545 \\
\hline \multirow[t]{2}{*}{$\mathrm{v}$} & Eco & 2.479613 & 2.173808 & 0.739045 & 1.298312 & 4.643362 & 0.797273436 \\
\hline & Conventional & 95.62282 & 33.92938 & 8192.4032 & 0 & 1180.037 & \\
\hline \multirow[t]{2}{*}{$\mathrm{Zn}$} & Eco & 53.31732 & 7.115225 & 5120.7712 & 0 & 881.4934 & \\
\hline & Conventional & 0.076824 & 0.004655 & 50.196429 & 0 & 1.212835 & $n / a$ \\
\hline \multirow[t]{2}{*}{$\mathrm{NO} 3$} & Eco & 0.20331 & 0 & 0.410216 & 0 & 1.832641 & $n / a$ \\
\hline & Conventional & 0.021063 & 0 & 0.109713 & 0 & 0.911662 & $n / a$ \\
\hline $\mathrm{PO} 4$ & Eco & 0.104938 & 0.050984 & 40.267167 & 0 & 2.052124 & $n / a$ \\
\hline
\end{tabular}




\section{Appendix D: Broken Stick Model}

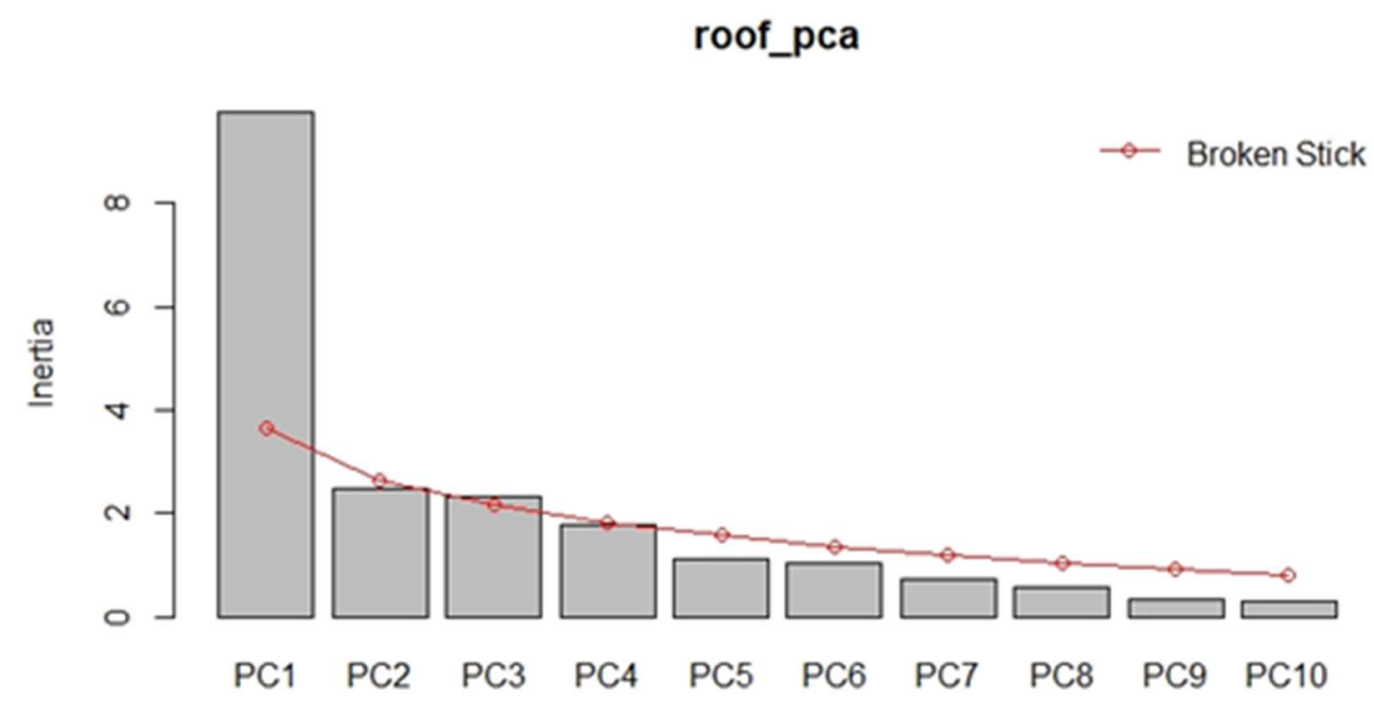

Figure A2. the broken stick model of the PCA analysis of conventional roof and ecoroof hydrology and unit area loads over the sampling period. 


\section{Appendix E: PCA Eigenvectors}

Table A3. The eigvenvectors of PC1 from the PCA analysis of conventional roof and ecoroof hydrology and unit area loads over the sampling period.

\begin{tabular}{|l|r|}
\hline & \multicolumn{1}{|c|}{ PC1 } \\
\hline $\mathrm{V}$ & 0.307887 \\
\hline $\mathrm{Mg}$ & 0.306131 \\
\hline $\mathrm{Sr}$ & 0.29973 \\
\hline $\mathrm{Na}$ & 0.298551 \\
\hline $\mathrm{Fe}$ & 0.29777 \\
\hline $\mathrm{As}$ & 0.294161 \\
\hline $\mathrm{B}$ & 0.291183 \\
\hline $\mathrm{Al}$ & 0.277552 \\
\hline $\mathrm{Ti}$ & 0.257862 \\
\hline $\mathrm{Mo}$ & 0.254684 \\
\hline $\mathrm{Ba}$ & 0.239933 \\
\hline $\mathrm{Cr}$ & 0.22186 \\
\hline $\mathrm{dis} \mathrm{I} / \mathrm{m} 2$ & 0.196159 \\
\hline $\mathrm{Cu}$ & 0.07839 \\
\hline $\mathrm{Ni}$ & 0.022126 \\
\hline $\mathrm{Co}$ & 0.01261 \\
\hline $\mathrm{Pb}$ & 0.007134 \\
\hline $\mathrm{Cd}$ & 0.006915 \\
\hline $\mathrm{Zn}$ & -0.00959 \\
\hline $\mathrm{Mn}$ & -0.0384 \\
\hline ret & -0.10205 \\
\hline
\end{tabular}




\section{Appendix F: Runoff Chemical Unit Area Loading Summary}

Table A4. The mean, median, standard deviation, minimum, and maximum and total unit

area loads for metals and nutrients from the conventional roof and ecoroof over the 27

storm events (17 storms for nutrients). Units are in $\mathrm{mg} / \mathrm{m}^{2}$. Bold denotes statistical

significance $(p<0.1)$.

\begin{tabular}{|c|c|c|c|c|c|c|c|}
\hline Chemical & Roof & Total & Mean & Median & SD & Min & Max \\
\hline \multirow[b]{2}{*}{ Al } & Conventional & 0.81 & 0.03 & 0.01 & 0.05 & 0.00 & 0.17 \\
\hline & Eco & 9.43 & 0.35 & 0.23 & 0.42 & 0.00 & 1.50 \\
\hline \multirow[b]{2}{*}{ As } & Conventional & 0.05 & 0.00 & 0.00 & 0.00 & 0.00 & 0.02 \\
\hline & Eco & 0.22 & 0.01 & 0.00 & 0.01 & 0.00 & 0.02 \\
\hline \multirow[b]{2}{*}{ B } & Conventional & 0.32 & 0.01 & 0.01 & 0.02 & 0.00 & 0.07 \\
\hline & Eco & 1.45 & 0.05 & 0.04 & 0.06 & 0.00 & 0.22 \\
\hline \multirow[b]{2}{*}{$\mathrm{Ba}$} & Conventional & 4.97 & 0.18 & 0.15 & 0.07 & 0.07 & 0.35 \\
\hline & Eco & 4.09 & 0.15 & 0.10 & 0.15 & 0.00 & 0.46 \\
\hline \multirow[b]{2}{*}{ Cd } & Conventional & 0.09 & 0.00 & 0.00 & 0.02 & 0.00 & 0.08 \\
\hline & Eco & 0.00 & 0.00 & 0.00 & 0.00 & 0.00 & 0.00 \\
\hline \multirow[b]{2}{*}{ Co } & Conventional & 0.07 & 0.00 & 0.00 & 0.01 & 0.00 & 0.05 \\
\hline & Eco & 0.05 & 0.00 & 0.00 & 0.00 & 0.00 & 0.02 \\
\hline \multirow[b]{2}{*}{$\mathrm{Cr}$} & Conventional & 0.02 & 0.00 & 0.00 & 0.00 & 0.00 & 0.00 \\
\hline & Eco & 0.04 & 0.00 & 0.00 & 0.00 & 0.00 & 0.01 \\
\hline \multirow[b]{2}{*}{$\mathrm{Cu}$} & Conventional & 0.17 & 0.01 & 0.00 & 0.02 & 0.00 & 0.06 \\
\hline & Eco & 0.43 & 0.02 & 0.00 & 0.04 & 0.00 & 0.19 \\
\hline \multirow[b]{2}{*}{$\mathrm{Fe}$} & Conventional & 1.92 & 0.07 & 0.03 & 0.12 & 0.00 & 0.52 \\
\hline & Eco & 8.88 & 0.33 & 0.25 & 0.34 & 0.00 & 1.08 \\
\hline \multirow[b]{2}{*}{$\mathrm{Mg}$} & Conventional & 26.98 & 1.00 & 0.75 & 0.80 & 0.13 & 3.23 \\
\hline & Eco & 222.94 & 8.26 & 5.32 & 8.28 & 0.00 & 28.28 \\
\hline \multirow[b]{2}{*}{$\mathrm{Mn}$} & Conventional & 0.88 & 0.03 & 0.01 & 0.05 & 0.00 & 0.19 \\
\hline & Eco & 0.09 & 0.00 & 0.00 & 0.01 & 0.00 & 0.02 \\
\hline \multirow[b]{2}{*}{ Mo } & Conventional & 0.03 & 0.00 & 0.00 & 0.00 & 0.00 & 0.00 \\
\hline & Eco & 0.05 & 0.00 & 0.00 & 0.00 & 0.00 & 0.01 \\
\hline \multirow[b]{2}{*}{$\mathrm{Na}$} & Conventional & 136.41 & 5.05 & 2.08 & 6.62 & 0.24 & 29.59 \\
\hline & Eco & 613.62 & 22.73 & 17.82 & 21.51 & 0.00 & 79.52 \\
\hline \multirow[b]{2}{*}{$\mathrm{Ni}$} & Conventional & 0.10 & 0.00 & 0.00 & 0.01 & 0.00 & 0.04 \\
\hline & Eco & 0.04 & 0.00 & 0.00 & 0.00 & 0.00 & 0.02 \\
\hline \multirow[b]{2}{*}{$\mathrm{Pb}$} & Conventional & 0.05 & 0.00 & 0.00 & 0.01 & 0.00 & 0.05 \\
\hline & Eco & 0.00 & 0.00 & 0.00 & 0.00 & 0.00 & 0.00 \\
\hline \multirow[b]{2}{*}{$\mathrm{Sr}$} & Conventional & 1.20 & 0.04 & 0.04 & 0.04 & 0.00 & 0.16 \\
\hline & Eco & 14.68 & 0.54 & 0.36 & 0.55 & 0.00 & 1.87 \\
\hline \multirow[b]{2}{*}{$\mathrm{Ti}$} & Conventional & 0.01 & 0.00 & 0.00 & 0.00 & 0.00 & 0.00 \\
\hline & Eco & 0.42 & 0.02 & 0.00 & 0.02 & 0.00 & 0.09 \\
\hline \multirow[b]{2}{*}{ V } & Conventional & 0.04 & 0.00 & 0.00 & 0.00 & 0.00 & 0.01 \\
\hline & Eco & 0.82 & 0.03 & 0.02 & 0.03 & 0.00 & 0.10 \\
\hline \multirow[b]{2}{*}{$\mathrm{Zn}$} & Conventional & 14.47 & 0.54 & 0.44 & 0.54 & 0.00 & 2.01 \\
\hline & Eco & 3.29 & 0.12 & 0.00 & 0.26 & 0.00 & 0.97 \\
\hline \multirow[b]{2}{*}{ NO3 } & Conventional & 12.96 & 0.76 & 0.16 & 1.35 & 0.00 & 5.17 \\
\hline & Eco & 9.15 & 0.51 & 0.01 & 1.13 & 0.00 & 4.24 \\
\hline \multirow[b]{2}{*}{ PO4 } & Conventional & 3.64 & 0.21 & 0.08 & 0.36 & 0.00 & 1.45 \\
\hline & Eco & 18.81 & 1.05 & 0.44 & 1.38 & 0.00 & 4.26 \\
\hline
\end{tabular}




\section{Appendix G: Roof Bulk Deposition Input Concentrations}

Table A 5. The total metal bulk deposition concentration input of metals from October 2018 to the end of May 2019.

\begin{tabular}{|l|r|}
\hline Chemical & Concentration (ppb) \\
\hline $\mathrm{B}$ & 4.07 \\
\hline $\mathrm{Na}$ & 665.27 \\
\hline $\mathrm{Mg}$ & 220.38 \\
\hline $\mathrm{Al}$ & 137.06 \\
\hline $\mathrm{Ti}$ & 4.61 \\
\hline $\mathrm{V}$ & 0.51 \\
\hline $\mathrm{Cr}$ & 0.94 \\
\hline $\mathrm{Mn}$ & 12.27 \\
\hline $\mathrm{Fe}$ & 230.33 \\
\hline $\mathrm{Co}$ & 0.63 \\
\hline $\mathrm{Ni}$ & 1.01 \\
\hline $\mathrm{Cu}$ & 7.94 \\
\hline $\mathrm{Zn}$ & 76.66 \\
\hline $\mathrm{As}$ & 0.15 \\
\hline $\mathrm{Sr}$ & 4.90 \\
\hline $\mathrm{Mo}$ & 0.14 \\
\hline $\mathrm{Cd}$ & 0.06 \\
\hline $\mathrm{Ba}$ & 8.81 \\
\hline $\mathrm{Pb}$ & 1.92 \\
\hline
\end{tabular}




\section{Appendix H: The Flow Chart of the Experiment Design}

Figure A3. The flow chart summary of this study's experimental design that investigated the chemistry the ecoroof and conventional roof runoff and the environmental and roof variables that affected it.

\begin{tabular}{|c|c|c|}
\hline $\begin{array}{l}\text { Collected conventional } \\
\text { roof and ecoroof samples } \\
\text { after storm event and } \\
\text { brought to lab within } 48 \\
\text { to } 72 \text { hours }\end{array}$ & $\begin{array}{l}\text { Sampled Filtered. Samples } \\
\text { for metal analysis acid } \\
\text { preserved. Samples for } \\
\text { nutrient analysis frozen }\end{array}$ & $\begin{array}{l}\text { Samples were analyzed } \\
\text { for metals with ICP-MS } \\
\text { and nutrients with } \\
\text { Smartchem }\end{array}$ \\
\hline \multirow{2}{*}{$\begin{array}{l}\text { Compared Unit area load } \\
\text { to Roof variables, historic } \\
\text { data, and other studies }\end{array}$} & $\begin{array}{l}\text { Unit area load calculated } \\
\text { per storm }\end{array}$ & \\
\hline & $\begin{array}{l}\text { Single and multivariate } \\
\text { statistical analysis }\end{array}$ & \\
\hline $\begin{array}{l}\text { Collected Bulk Deposition } \\
\text { Every 2-4 weeks. }\end{array}$ & & \multirow{2}{*}{$\begin{array}{l}\text { Hydrology data } \\
\text { processed: base flow } \\
\text { removed and storm } \\
\text { separation }\end{array}$} \\
\hline $\begin{array}{l}\text { Historic ecoroof media } \\
\text { chemistry from the last } 5 \\
\text { years. }\end{array}$ & & \\
\hline \multirow[t]{2}{*}{ Gutter blanks } & & Flume hydrology data \\
\hline & & $\begin{array}{l}\text { Weatherstation } \\
\text { environmental data }\end{array}$ \\
\hline
\end{tabular}

